\title{
The ABC of Phytohormone Translocation
}

Authors

Affiliation
Eva Hellsberg, Floriane Montanari, Gerhard F. Ecker

University of Vienna, Department of Pharmaceutical Chemistry, Vienna, Austria

\author{
Key words \\ - Petunia hybrida PDR1 \\ - Solanaceae \\ - Arabidopsis thaliana \\ - Brassicaceae \\ - ABC transporters \\ - phytohormone transport \\ - homology modelling
}

\section{Abstract \\ $\nabla$}

ATP-driven transport across biological membranes is a key process to translocate solutes from the interior of the cell to the extracellular environment. In humans, ATP-binding cassette transporters are involved in absorption, distribution, metabolism, excretion, and toxicity, and also play a major role in anticancer drug resistance. Analogous transporters are also known to be involved in phytohormone translocation. These include, e. g., the transport of auxin by ABCB1/19 in Arabi- dopsis thaliana, the transport of abscisic acid by AtABCG25, and the transport of strigolactone by the Petunia hybrida ABC transporter PDR1. Within this article, we outline the current knowledge about plant $A B C$ transporters with respect to their structure and function, and provide, for the first time, a protein homology model of the strigolactone transporter PDR1 from P. hybrida.

Supporting information available online at http://www.thieme-connect.de/products received August 12, 2014 revised February 19, 2015 accepted February 23, 2015

\section{Bibliography}

DOI http://dx.doi.org/ 10.1055/s-0035-1545880

Published online April 23, 2015

Planta Med 2015; 81: 474-487

(c) Georg Thieme Verlag KG

Stuttgart · New York .

ISSN 0032-0943

\section{Correspondence}

Gerhard F. Ecker

University of Vienna

Department of Pharmaceutical

Chemistry

Althanstraße 14

1090 Wien

Austria

Phone: + 431427755110

Fax: +4314277855110

gerhard.f.ecker@univie.ac.at

\section{Introduction}

ATP-binding cassette transporters (ABC transporters) represent a huge superfamily of proteins expressed in all phyla from prokaryotes to humans. In humans, they attract a lot of interest due to their role in multidrug resistance in cancer therapy, their involvement in drug/drug interactions, as well as their influence on the bioavailability and toxicity of drugs. $A B C$ transporters are characterized by a nucleotide binding domain (NBD), which hydrolyzes ATP and provides energy for the conformational changes required for solute transport across the membranes, and a transmembrane domain (TMD), which forms a pore through which the substrates pass. Some soluble members of the $A B C$ transporters only contain NBD, while the full-size members contain two NBD modules and two TMD modules. The socalled half-size $A B C$ transporters are built out of one NBD and one TMD, and require dimerization for the transport activity (O Fig. 1 ). ABC transporters in humans comprise 48 proteins and are classified into six families (ABCA-ABCG), with the multidrug resistance protein 1 (MDR1, P-glycoprotein; gene $A B C B 1)$, the breast cancer resistance protein (BCRP; gene ABCG2), and the multidrug resistance-related protein 1 (MRP1; gene
$A B C C 1$ ) being the most prominent ones. In plants, more than 100 genes coding for $A B C$ transporters have been discovered to date. Plant $A B C$ transporters cluster in eight families, from $A B C A$ to $A B-$ $\mathrm{CI}$ (the $\mathrm{ABCH}$ subfamily has not been found in plants). While in humans the ABCG family only consists of half-size transporters, plant ABCG transporters may be half or full size [1].

The plants lack a developed and dynamic vascular system, which may explain their need for an elaborated transport system to allow a proper distribution of nutrients and signals [2]. Two types of transport happen in plants: the long-range transport, where substances flow from root to shoot and back using the xylem and phloem vessels, and the short-range transcellular transport via the apoplastic compartments. Transport proteins, carriers, and permeases are involved in the latter type, allowing substances to pass from cell to cell, and from cell to vessel [2].

In analogy to humans, also in plants, hormones are essential for vegetative growth and development. Hormones are small molecules guarding signalling processes throughout the whole plant. Several of them have been known for a long time, including auxins, abscisic acid, cytokinins, gibberellins, and ethylene. In the last years, several more were discovered, such as brassinosteroids, jas- 


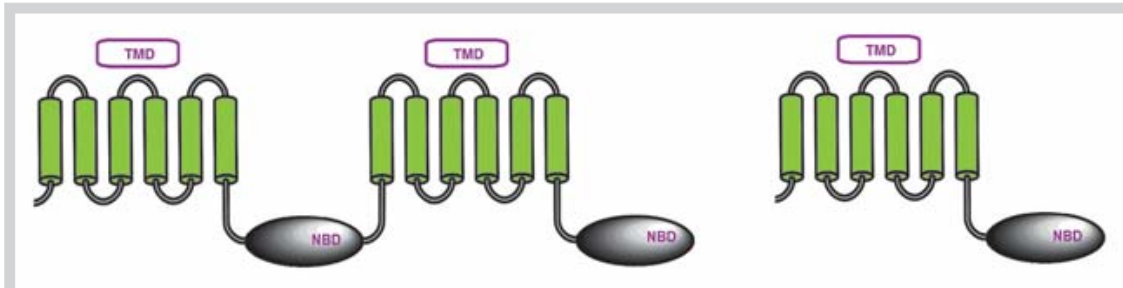

Fig. 1 Topology of a full and a half transporter. $\mathrm{TMD}=$ transmembrane domain, NBD = nucleotide binding domain. (Color figure available online only.)

monic acid, nitric oxide, salicylic acid, and strigolactones [3]. This group will likely grow even further in the coming years. As hormones take effect not only locally in the area of their biosynthesis but also in distant tissues, an adequate transport system is required.

In this article, we will provide an overview of the different roles of $A B C$ transporters in plants, with a focus on hormone transport and available structural information on the $A B C$ transport proteins involved. Finally, we will outline our protein homology modelling studies of a specific hormone transporter, PDR1 in Petunia hybrida (Solanaceae).

\section{Multiple Roles of ATP-Binding Cassette Transporters in Plants \\ $\nabla$}

Plant genomes contain more than 100 genes encoding ABC transporters [1]. Although a lot of work remains in order to identify the specific roles of each of those proteins across plant species, the current knowledge already reveals multiple critical functions. While it is not the aim of this article to extensively cover these roles (for detailed reviews, see [1] or [4]), we will briefly describe the main elucidated roles of $A B C$ transporters in plants.

\section{Detoxification}

$\nabla$

The first role ever discovered for $\mathrm{ABC}$ transporters in plants was detoxification and elimination of toxic endo- and xenobiotics [5]. While the global detoxification pathway is similar to the one known for humans (oxidation by cytochrome P450, followed by a conjugation with a hydrophilic moiety like glucuronide or glutathione), the excretion step of the conjugated toxins towards the vacuolar compartment or the apoplasm is done by $A B C$ transporters [5] such as AtABCC1, AtABCC2, and AtABCC3 [6-8]. ABCG36 in Arabidopsis thaliana (Brassicaceae) was shown to excrete cadmium from root hairs and root epidermal cells [9] towards the rhizosphere. Some results also point towards ABCG40 as a potential lead $(\mathrm{Pb})$ extruder [10], which is surprising considering the fact that AtABCG40 is also involved in hormone import. In humans, similar metal transport roles are taken up by the solute carrier DMT1 (SLC11A2) [11].

Aluminium toxicity is a well-studied phenomenon because of its impact on crop yield. In acid soils, aluminium is present as $\mathrm{Al}^{3+}$, which inhibits root growth with a subsequent decrease of shoot growth and overall crop productivity. Plants cope with Al toxicity by limiting the uptake and chelating internalized Al with malate or citrate. Recently, one Al-sensitive mutation was characterized in a previously uncharacterized half-size $A B C$ transporter [12] expressed throughout the phloem and the epidermis of the roots in A. thaliana. The authors propose that this transporter helps remove $\mathrm{Al}$ from sensitive tissues and sequestrates it into more tol- erant ones. Another Al-sensitive mutant in a different $A B C$ transporter, AtABCB27, was also identified. It may facilitate vacuolar sequestration of $\mathrm{Al}$ in the roots [13].

\section{Symbiosis and rhizosphere community}

Via their roots, plants are in close contact with soil fungal and bacterial communities. In legumes, this contact turned into a beneficial symbiosis between specific bacterial strains that take care of nitrogen fixation while the plant is in charge of the photosynthesis of nutrients [14]. The legumes recruit their symbiosis partners via flavonoid excretion from the roots. Recent studies showed that $A B C$ transporters, potentially of the PDR family, are involved in genistein and daidzein secretion in soybean $[15,16]$. Each plant species has its particular soil composition [17] that can change during the development of the plant [18]. This characteristic may be due to different abilities of roots to capture nutrients from the soil, as well as different exudations. Badri and colleagues, working on phytochemical exudations, showed that abcg30 mutants in A. thaliana significantly altered the amount and nature of microbial and fungal communities surrounding the roots. The phytochemicals excreted by the mutants lacking AtABCG30 were enriched in phenolic compounds such as benzoic acid or salicylic acid, and impoverished in glucose, fructose, or mannitol [19]. While no transport assays were performed in their study, the authors show that the absence of AtABCG30 resulted in pleiotropic effects in the mutants, with several transport genes overexpressed while sugar transporters were downregulated. The mutants were surrounded by a different microbiota, enriched in bacteria strains able to fixate nitrogen or to detoxify heavy metals and other pollutants. The experiment shows that lacking only one $\mathrm{ABC}$ transporter might completely change the expression pattern of other transporters and have consequences on the plant surroundings, including the neighbouring microbiota.

$\mathrm{ABC}$ transporters in roots seem to play a critical role in the establishment of an appropriate rhizobia for the plant. Controlling $A B C$ transporter's root exudations could be a way of modifying the soil contents for beneficial purposes.

\section{Metabolite transport}

Metabolite transport is a broad subject. Table 1 provides an overview on the most prominent examples of $A B C$ transporters involved in metabolite transport together with their specific tasks in plants.

AtABCC2 (AtMRP2) has been known for a long time to be involved in the transport of glutathione S-conjugates and chlorophyll catabolites [7]. Glutathione is necessary for the reduction of dehydro-L-ascorbic acid to ascorbic acid, and this process is crucial for hydrogen peroxide detoxification [20]. Chlorophyll is naturally catabolized during leaf senescence, and the metabolites are accumulated in the vacuole [21]. 


\begin{tabular}{|c|c|c|c|}
\hline Transporter & Plant & Substrates & Reference \\
\hline AtABCC2 & A. thaliana & $\begin{array}{l}\text { gluthathione conjugates } \\
\text { chlorophyll catabolites }\end{array}$ & Lu et al., 1998 [7] \\
\hline AtABCC5 & A. thaliana & phytate $\left(\mathbb{P}_{6}\right)$ & Nagy et al., 2009 [22] \\
\hline AtABCD1 & A. thaliana & $\begin{array}{l}\text { CoA esters of fatty acids } \\
\text { indole-3-butyric acid }\end{array}$ & Zolman et al., 2001 [23] \\
\hline CjMDR1 & C. japonica & berberines & Yazaki et al., 2001 [24] \\
\hline AtPDR2 & A. thaliana & amino acids & Badri et al., 2008 [27] \\
\hline AtABCG34 & A. thaliana & organic acids & Badri et al., 2008 [27] \\
\hline
\end{tabular}

Table 1 Metabolite ATP-binding cassette transporters.
AtABCC5 transports phytate $\left(\mathrm{IP}_{6}\right)$, which is an important phosphorus supplier, into the vacuole. $\mathrm{IP}_{6}$ is a messenger in guard cells, where it is essential for correct stomatal movement. In seeds, it helps storing metallic cations by chelating them [22]. Fatty acid $\beta$-oxidation is needed to build up acetyl-CoA for the citric acid cycle. ABCD1 (PXA1) in A. thaliana imports coenzyme A esters of fatty acids and indole-3-butyric acid (a precursor of auxin) into the peroxisome to enable the oxidation process [23]. The ABC transporter MDR1 uptakes berberines in Coptis japonica. As a consequence, the isoquinoline alkaloids accumulate in the rhizome [24]. They are synthesized in the roots, reach the rhizome through connecting xylem tissues, and are finally uptaken by CjMDR1, which is therefore working as a cell importer, probably the least common transport direction among the $\mathrm{ABC}$ transporters in eukaryotic cells [25]. The real use of berberines for the plant remains unclear, although there is an assumption for feedback regulation in berberine biosynthesis [26].

Badri et al. presented another extensive investigation about the connection of root exudates with $\mathrm{ABC}$ transporters by studying six full-length and one half transporters derived from MRP, PDR (pleiotropic drug resistance), and PGP (P-glycoprotein) subfamilies in $A$. thaliana. Their experiments were mainly based on comparisons of certain metabolites in the root exudates between transporter knockout and wild-type plants. Within their studies, they proved that $A B C$ transporters are involved in the root secretion process and that there can be many transporters involved in the secretion of one metabolite, or a single transporter can be involved in the pathways of many metabolites [27] ( Table 1 ).

\section{Immunity}

Several members of the PDR subfamily of ABC transporters have been found to protect distinct plant species from infection by pathogens. For example, the silencing of Nicotiana plumbaginifolia PDR1 increased the sensitivity of the plant to fungal and oomycete pathogens [28]. In A. thaliana, dysfunctional mutants of the gene ABCG36 (PDR8) become more sensitive to infectious bacterial strains [29], and ABCG40 (PDR12) is overexpressed when exposed to fungal pathogens [30].

While it is not quite clear how those full-length G family transporters help the plants to resist against bacterial and fungal infections, the study of their substrates and the phenotypes of mutant plants shed light on the transporter-associated immune system of plants. ABCG31 in Hordeum vulgare (barley), as well as ABCG11 and ABCG12 in A. thaliana, help the formation of the cuticle, which can be seen as the first protective barrier of the plant [31-33], thus indirectly contributing to the protection of the plant against stresses and infections. Another hypothesis would be the excretion of toxic secondary metabolites; the already mentioned NPPDR1 was found to secrete sclareolide, an antifungal diterpene, on the leaf surface [34]. Also, flavonoids have recognized antimicrobial and antioxidative properties [35,36], and it was recently shown that ABCG10 in Medicago truncatula (MtABCG10) modulates the isoflavonoid levels [37]. Anyway, suppression of MtABCG10 leads to a lower resistance of the plant to the root pathogen Fusarium oxysporum.

\section{Hormone transport}

Plant ABC transporters of the B and G family are also involved in the transport of phytohormones like auxins, abscisic acid, cytokinins, or strigolactones. The details are explained in the next section.

\section{Phytohormone ATP-Binding Cassette Transporters} $\nabla$

\section{Auxin transport}

The phytohormone auxin (whose main natural form is indole-3acetic acid, IAA) is involved in root development [38], vascular differentiation [39], cell wall construction [40], plant growth [41], as well as in response to light (reviewed in [42]) or gravity [43]. Auxin transport has been extensively studied in the model plant $A$. thaliana. While the plant vascularization by xyleme and phloeme can carry phytohormones from the root to the stem apex or the reverse, lateral transport from biosynthesis loci (shoot apex, leaves, and roots [44]) to these vessels requires what is called the polar auxin transport [2]. The current model of polar auxin transport includes a family of import proteins, the permease-like AUX carriers [43]. In the acidic apoplastic compartment, around $20 \%$ of auxin is in its neutral, undissociated form and can therefore cross the plasmic membrane by passive diffusion [45]. On the other side, since a long time auxin efflux is thought to involve protein complexes [46]. More recent discoveries identified the plant-specific pin-formed (PIN) family [47] as an auxin export carrier. In addition, several members of the $B$ subfamily of $A B C$ transporters are also able to transport auxin: Pgp1 (ABCB1) and Pgp19 (ABCB19) [48], Pgp4 (ABCB4) in the roots [49], and Pgp14 (ABCB14) and Pgp15 (ABCB15) during the stem lignification [50].

The most studied ABC transporters, Pgp1 and Pgp19, seem to play a crucial role in polar auxin transport; co-expressed in a polarized manner with the PIN members PIN1 or PIN2, they stabilize their membrane trafficking and localization [51]. Pgps, in association with the PIN proteins, synergistically participate in auxin efflux after receiving regulatory signals from their protein partners of the immunophilin TWD family $[52,53]$. Protein-protein binding occurs between Pgp and TWD, which increases the efflux activity of the entire system ( $\bullet$ Fig. 2 ). Such protein-protein binding concerning an $\mathrm{ABC}$ transporter and a soluble immunophilin is not well studied in humans, and the potential impact of $A B C$ transporters in membrane trafficking of other membrane proteins probably deserves some attention in humans, too. 


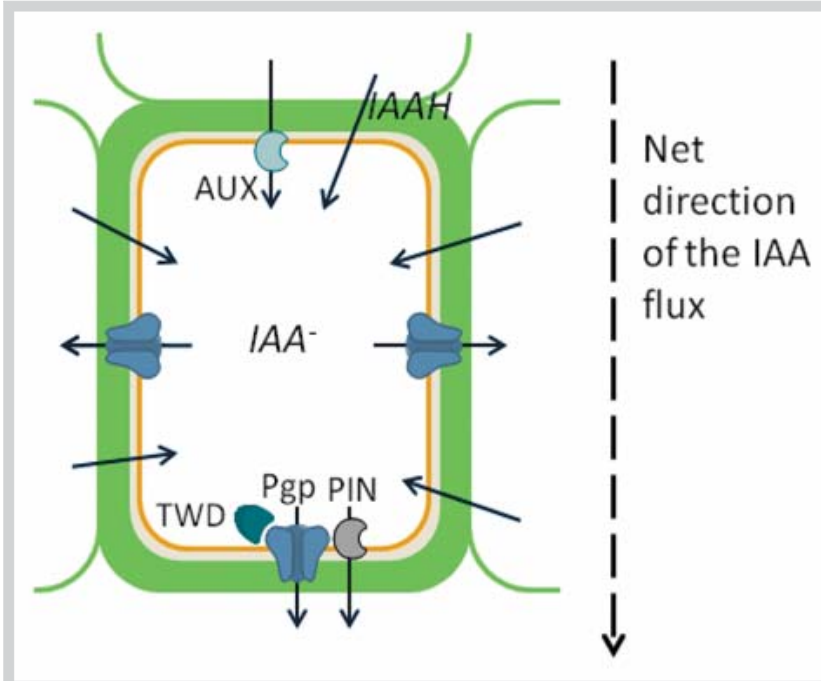

Fig. 2 Schema of directional auxin flux and role of the different transporters. Adapted from Blakeslee et al. [44]. (Color figure available online only.)

However, Pgps also have a nonpolar localization in small meristematic cells where they oppose the passive rediffusion of protonated auxin from the membrane, which otherwise could disrupt the polar transport. In those lateral membranes, Pgps would therefore not be linked to PIN proteins, but function as individual auxin efflux transporters ( $\odot$ Fig. 2) [44].

Recently, a specific role of Pgp19 in phototropism was discovered by Christie et al. [54]. Phototropism is the asymmetric stem growth phenomenon occurring when the plant is only partially enlightened. In this case, an auxin gradient is created that makes the distal side of the stem grow faster than the enlightened side, resulting in a bending of the stem. The protein kinase phot1 is sensitive to light, and, upon illumination, will phosphorylate the cytosolic C terminal region of Pgp19, resulting in an inhibition of auxin efflux. The subsequent auxin accumulation will then serve for the lateral flux towards the shadowy side of the stem. The authors hypothesize that the phosphorylation actually inhibits the interaction between Pgp19 and its activator TWD1.
A parallel phenomenon has been reported for Pgp1. The serinethreonine protein kinase PINOID (PID) is a partner of the TWD1Pgp efflux complex. In the absence of TWD1, phosphorylation of Pgp1 by PID leads to a higher activity of auxin efflux. But when TWD1 is bound to its $A B C$ transporter partner, the result of PID action is a complete abolition of auxin transport [55].

Polar transport of the plant hormone auxin is controlled by PINand $A B C B / P G P$ efflux catalysts. PIN polarity is regulated by the AGC protein kinase, PINOID (PID), while ABCB activity was shown to be dependent on the interaction with the FKBP42, TWISTED DWARF1 (TWD1). Using co-immunoprecipitation (co-IP) and shotgun LC-MS/MS analysis, PID was identified as a valid partner in the interaction with TWD1. In vitro and yeast expression analyses indicated that PID specifically modulates ABCB1-mediated auxin efflux in an action that is dependent on its kinase activity and that is reverted by quercetin binding and thus the inhibition of PID autophosphorylation. Triple ABCB1/PID/TWD1 cotransfection in tobacco (Nicotiana benthamiana) revealed that PID enhances $A B C B 1-$ mediated auxin efflux, but blocks $A B C B 1$ in the presence of TWD1. Phosphoproteomic analyses identified S634 as a key residue of the regulatory $\mathrm{ABCB} 1$ linker and a very likely target of PID phosphorylation that determines both transporter drug binding and activity. In summary, this study provides evidence that PID phosphorylation has a dual, counteractive impact on ABCB1 activity that is coordinated by the TWD1-PID interaction.

Auxin transport is not exclusively regulated by a protein-protein interaction and phosphorylation of Pgps. Endogenous and exogenous small molecules are also known to inhibit the auxin transporters. The family of phytotropins was described in the 70s as auxin transport inhibitors. They share a 2-carboxyphenyl group linked to another aromatic system [56]. Selected structures of phytotropins are shown in 0 Fig. 3, notably, the 1-N-naphthylphtalamic acid (NPA), the cyclopropyl propane dione (CPD), the 2-(1-pyrenoyl)benzoic acid (BPA), and DPX1840. The pharmacophoric features elucidated by Katekar comprise a carboxylic acid moiety (or equivalent), coplanarity of the two aromatic rings, and a distance of $7.3 \mathrm{~A}$ between the two aromatic rings. The common effect of the members of this family is a blockage of the polar auxin transport, a biphasic root growth inhibition, and a loss of gravitropism [57]. Katekar and Geissler were able to show that NPA has a weak auxin-like behavior at a low concentration, and that NPA and CPD share the same target. More recently, it was shown

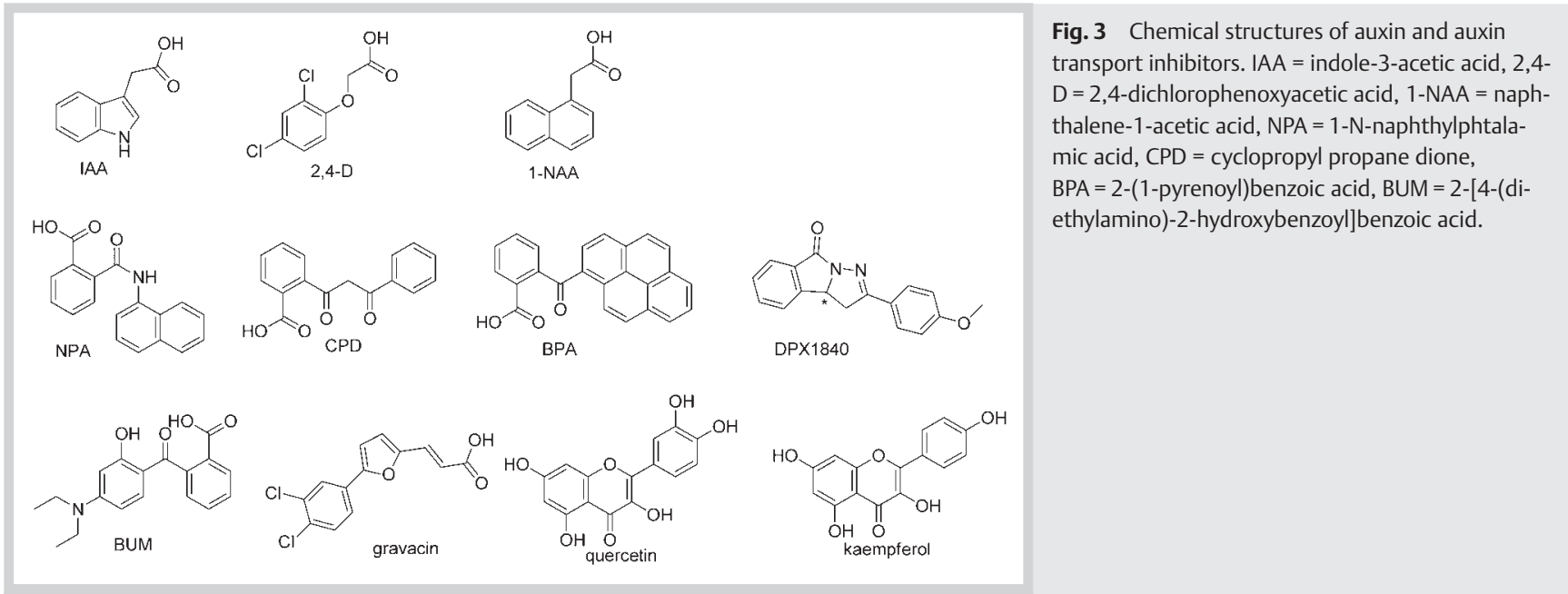




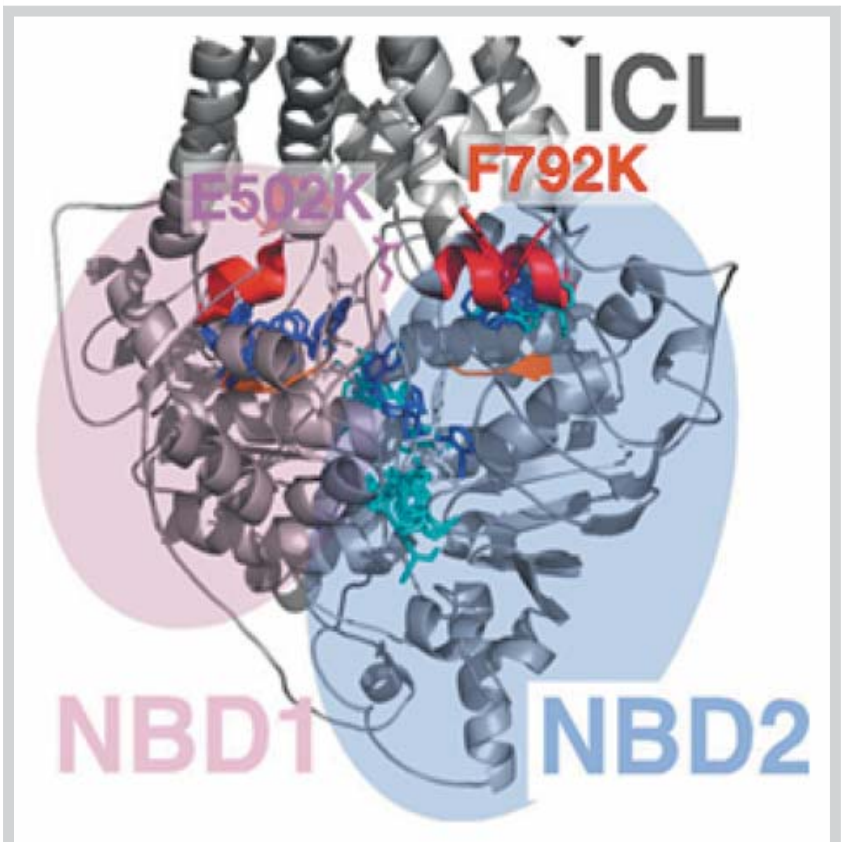

Fig. 4 In silico drug binding to the $\mathrm{N}$ - and $\mathrm{C}$-terminal $\mathrm{ABCB} 1$ nucleotidebinding folds (NBD1 and -2 ) suggest overlapping and distinct inhibitor binding pockets for BUM (cyan) and NPA (blue). Note that NPA docks to pockets flanked by coupling helices (red) and the Q loop (orange) of NBD1 and NBD2, whereas BUM docks only to the pocket corresponding to NBD2. Relevant residues Glu502 and Phe792 mutagenized under C are represented as pink and red sticks. Research as originally published in Kim et al. [60]; ๑ American Society for Biochemistry and Molecular Biology. (Color figure available online only.)

that NPA acts by disrupting the protein-protein interaction between Pgp1 and TWD1 [53], that the loss of photo- and gravitropism in $A$. thaliana hypocotyls is due to an inhibition of Pgp19 [58], and that it is also an inhibitor of Pgp4 [59] and Pgp1 [52].

Docking into an homology model of Pgp1 revealed that NPA binds in the nucleotide binding domain (NBD) region at the interface with the transmembrane domain ( Fig. 4) [60]. This is further supported by site-directed mutagenesis, which showed that a mutation in this region (E502K) abolishes NPA binding. Kim and colleagues also presented a new Pgp inhibitor, 2-[4-(diethylamino)-2-hydroxybenzoyl]benzoic acid (BUM, - Fig. 3), which is 30 times more potent than NPA. BUM also binds to the NBDs and disrupts the interaction with the TWD partner.

Gravacin, the 3-(5-[3,4-dichlorophenyl]-2-furyl)-acrylic acid ( Fig. 3), is an inhibitor of root and shoot gravitropism, inhibits the response to auxin [61,62], and specifically Pgp19 (and not Pgp1). Gravacin displaces $60 \%$ of NPA bound to Pgp19, which may indicate a partial overlap of their respective binding sites. However, gravacin does not disrupt the interaction between TWD and Pgp19.

Finally, flavonoids have also been shown to interact with plant $\mathrm{ABC}$ transporters. Those endogenous metabolites are synthesized widely among the plant kingdom and inhibit $\mathrm{ABC}$ transporters in mammals [63] via binding to the NBDs. In A. thaliana and Cucurbita pepo hypocotyls, quercetin, and kaempferol ( Fig.3) decrease auxin efflux in an NPA-competitive fashion [64].

Strikingly, although ABC transporters in mammalians are able to transport a wide range of substrates, the substrate specificity of auxin efflux Pgps in plants is quite high. They are only able to transport indole-3-acetic acid (IAA, the main form of auxin), 2,4-dichlorophenoxyacetic acid (2,4-D) and naphthalene-1-acetic acid (NAA; - Fig. 3; [48]). Bailly and colleagues [65] compared the properties of the translocation chambers of Pgp1 and Pgp19 obtained by homology modelling with the crystal structure of mouse Pgp (ABCB1, [66]). The authors observed very little conservation between plant and animal Pgps in terms of the residues exposed to the cavity. Plant auxin exporters share a common surface electrostatic pattern in the translocation chamber; near the entrance, the potentials are negative, then evolve towards neutral potentials close to the binding zones. The mammalian electrostatic surfaces are much more diverse, which may explain the diversity of substrates seen in mammalian $A B C$ transporters (๑ Fig. 5).

To summarize, several members of the B family of ABC transporters in plants have been shown to play an important role in polar auxin efflux, both by direct transport and by facilitating and regulating the export by PIN proteins. Phosphorylation of the nucleotide binding domain and protein-protein interactions may also modulate their activity. This mechanism is not well studied in human ABC transporters, but could be highly relevant

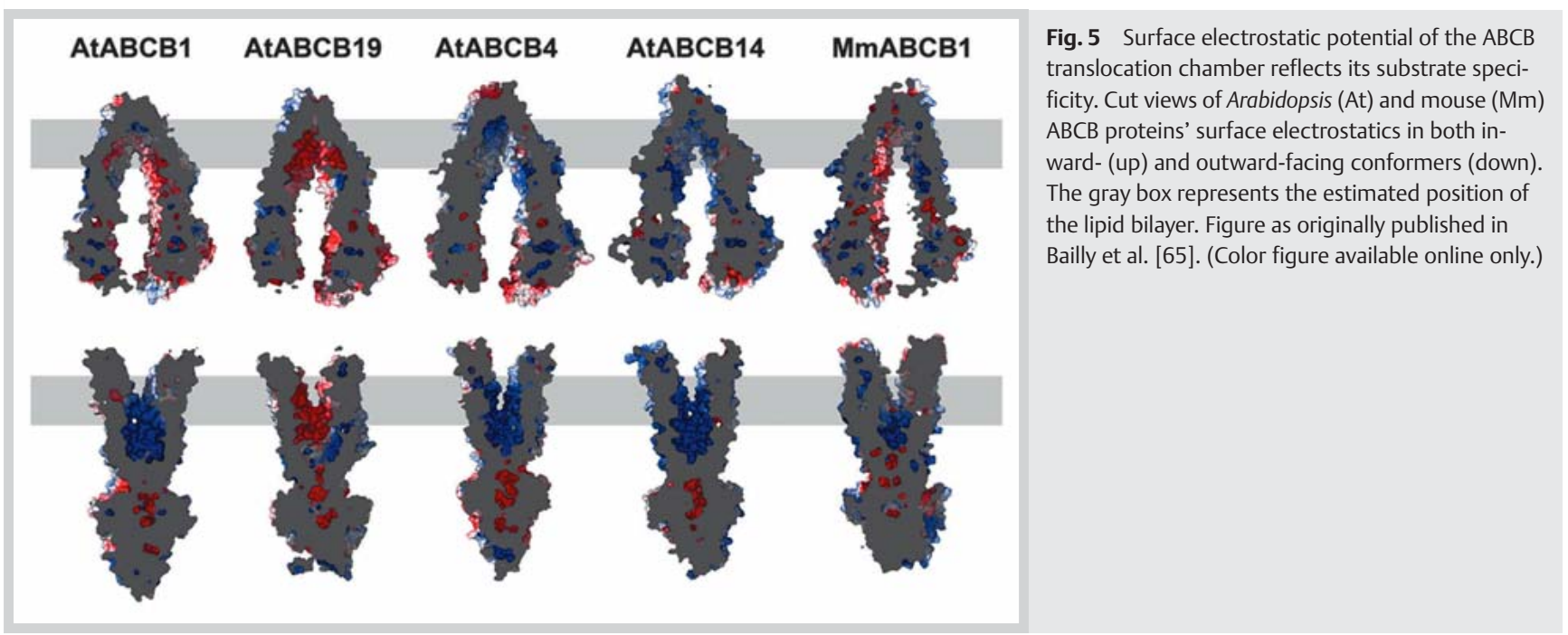




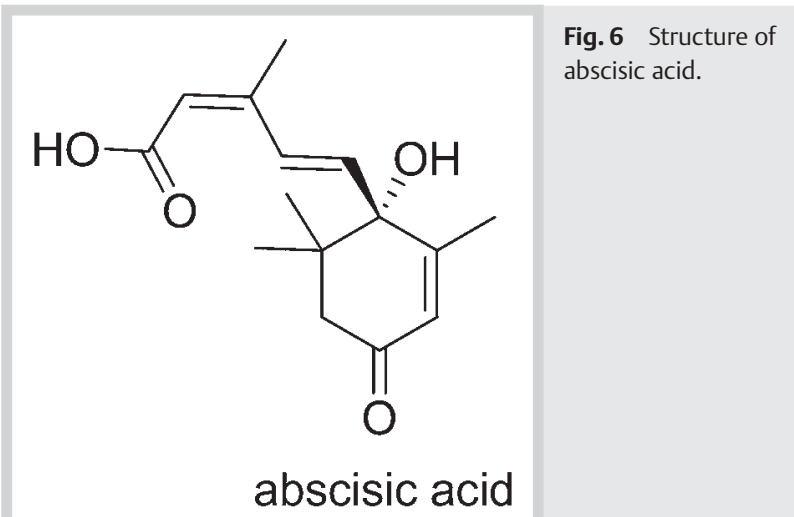

there, too. The substrate specificity of plant $A B C$ transporters is quite opposite to the promiscuity reported for animal $A B C$ transporters, which might be due to specific electrostatic patterns in the translocation chambers.

\section{Abscisic acid transport}

Abscisic acid (ABA) is a plant hormone that regulates developmental aspects like germination [67], and modulates resistance to drought [68], high salinity [69], or even pathogen infection [70].

During drought, the levels of ABA increase in the plants, leading to a closure of the stomatal pore triggered by a change of shape of the guard cells. The closure of the stomata reduces water loss by transpiration. On the contrary, when the humidity levels are high, CYP707 enzymes are expressed that oxidize and degrade the stock of ABA. CYP707A3 reduces the amount of ABA in vascular tissues, while CYP707A1 acts in the guard cells [71].

For obvious agricultural applications, it is essentially the link between $\mathrm{ABA}$ and water stress resistance that has attracted the interest of researchers over the last decades. It is known that, upon water stress, $A B A$ is synthesized in vascular parenchymal cells $[72,73]$. Given that the essential action site of $A B A$ under drought conditions is in the guard cells, the question of the transport of ABA from the vascular companion cells to the stomata arises [74]. $A B A$ is a weak acid ( $\bullet$ Fig. $\mathbf{6}$ ), thus, like auxin, it can diffuse passively into cells when it is in its undissociated form [75]. However, passive diffusion and local biosynthesis of $A B A$ in the guard cell [73] can explain neither the amount of ABA found in guard cells nor the fast response of the plant upon stress signalling. In 2009, Kang and colleagues [75] identified the ABC transporter PDR12 (ABCG40) in A. thaliana as necessary for a timely response to drought in guard cells and also for normal seed germination. Localized in the plasma membrane, this protein is expressed in the guard cells, in the seedlings, and in the roots. PDR12 expression is $A B A$ sensitive; when the plants are treated with $A B A$, the expression of PDR12 increases. A. thaliana mutants lacking PDR12 become more sensitive to drought than the wild-type plants.

The substrate specificity of PDR12 is high, as only the natural stereoisomer S-ABA can be transported, not the synthetic R-ABA or ABA-glucose-ester, auxin, or benzoic acid. However, ABA import to the guard cells is inhibited by the classical $A B C$ transporter inhibitors glibenclamide and verapamil.

But how does ABA leave the phloem companion cells and xylem parenchyma cells where it is synthesized? In 2010, Kuromori and colleagues screened various $A$. thaliana mutant lines for germination phenotypes and identified ABCG25 as an ABA exporter [72,
76]. Upon overexpression of this $A B C$ transporter, the germination growth is inhibited because of an accumulation of $A B A$ in the seeds. The authors found that, in adult plants, ABCG25 is coexpressed in the vascular system with the enzymes that catalyze ABA biosynthesis. Also, ABCG25 seems highly specific for S-ABA [76].

Yet another $A B C$ transporter seems to be involved in drought sensitivity, maybe via the transport of $A B A$ :ABCG22, another halftransporter from the ABCG subfamily that was recently discovered in A. thaliana because of its link with water transpiration and drought resistance [77]. The gene is expressed at the plasma membrane of stem, fruit, flower, and leaf cells. When knocked out, the mutants lack drought resistance, but no direct proof of ABA transport has been shown yet for this transporter.

\section{Cytokinin transport}

Cytokinins (CK) are, as their name suggests, responsible for cytokinesis, which is the final stage in cell division. They are also involved in many other developmental processes of plants: delay of leaf senescence [78], control of root/shoot balance [79], transduction of nutritional signals [80], differentiation of plant cells [81], chloroplast development and chlorophyll retention [82], and stress responses [79]. Thus, the whole plant morphology is influenced by the endogenous level of CKs.

Kinetin ( $\bullet$ Fig. 7) was the first CK discovered in 1955. Until today there is no consensus about whether it occurs naturally or not $[83,84]$. There are two classes of CKs [85]: purines and phenylurea derivatives ( $\odot$ Fig. 7). The former can be divided into isoprenoid and aromatic CKs ( $\bullet$ Fig. 7 ).

Depending on the nature of the side chains, the individual CKs have different activities, functions, or tissue localizations. In A. thaliana, for example, the main CKs are trans-zeatin and isopentenyl adenin ( $\mathbf{O}$ Fig. 7) [81]. Trans-zeatin is transported through the xylem [86], whereas isopentenyl adenin is the main CK in the phloem [87]. This different distribution of the individual agents in different tissues suggests that CKs act not only as local, but also as long-distance signals [88]. This finding suggests the presence of a transport system for CKs in plants. The involvement of the A. thaliana purine permease family (AtPUP) and most likely of a representative of the equilibrative nucleoside transporters (ENT) to the translocation of cytokinins has been known for quite some time $[88,89]$.

The most actual findings report that an $A B C$ transporter of the $G$ family is involved in CK transport from root to shoot. A recent publication on this topic by Ko et al. describes that AtABCG14, mainly expressed in the root, is essentially involved in the $\mathrm{CK}$ transport to the shoot by allowing for the loading of CKs to the xylem sap, thus enabling all further translocations [90]. In their study, candidate $\mathrm{CK}$ transporters were selected by the expression of colocalization with CK biosynthesis genes in the root and other genes induced by $\mathrm{CK}$ treatment. Among the candidates, the seedlings with atabcg14 mutants showed a different shoot to root ratio, smaller leaves, and longer roots. The mature plants exhibited smaller rosette leaves, shorter and thinner stems, a lower number and size of xylem and phloem cells, smaller lignin level, and fewer seeds. All of these phenotypes could be reverted by external application of CKs. The atabcg14 mutants had reduced the root-to-shoot translocation of CKs, and the tZ-type CKs concentration in the xylem sap was reduced by more than $90 \%$. Finally, grafting a mutant atabcg14 shoot onto a wild-type root caused recovery of the shoot growth. These experimental results show that root-synthesized CKs are essential for shoot growth. 
<smiles>C/C=C\CNc1ncnc2[nH]cnc12</smiles>

isopentenyl adenine (iP)<smiles>C/C(=C\CNc1ncnc2[nH]cnc12)CO</smiles>

trans-zeatin (tZ)<smiles>CC(=CCNc1ncnc2[nH]cnc12)CO</smiles>

cis-zeatin (cZ)<smiles>C[C@H](CO)CCNc1ncnc2[nH]cnc12</smiles>

dihydrozeatin (DZ)<smiles>c1coc(CNc2ncnc3[nH]cnc23)c1</smiles><smiles>c1ccc(CNc2ncnc3nc[nH]c23)cc1</smiles>

benzylaminopurine<smiles>Oc1cccc(CNc2ncnc3[nH]cnc23)c1</smiles><smiles>O=COOCCO</smiles>

o-topolin<smiles>O=C(Nc1ccccc1)Nc1cnns1</smiles>

Fig. 7 Chemical structures of the most known cytokinins. DPU =1,3-diphenylurea, CP PU = N-(2-chloro-4-pyridyl)-N ${ }^{\prime}-$ phenylurea, $T D Z=$ thidiazuron<smiles>[R14]CO[R16](=O)O[Na]</smiles>

Fig. 8 Chemical structures of selected strigolactones. Upper row: naturally occurring SLs; lower row: synthetic analogues.

\section{Strigolactone transport}

Strigolactones (SLs) are carotenoid-derived plant hormones that play a central role in the regulation of shoot branching by suppressing the bud outgrowth activity [91,92].

The naturally occurring SLs [93] are divided into two major families, one with the BCD rings of strigol as a leading scaffold and the other one with the BCD rings of the natural orobanchol stereoisomer ( Fig. 8). Furthermore, additional SLs have been described which do not belong to these two families [94]. In addition, numerous synthetic analogs of SLs are known, with GR24 (๑ Fig. 8) having evolved as a reference compound. Finally, fluo- rescent analogs have also been developed, such as EGO 5 and ST 23b (॰ Fig. 8) [95].

Besides their function in branching inhibition, SLs are growth activators of arbuscular mycorrhizal fungi (AMF) [96], which live in a symbiosis with most of the land plants. The greatest benefit for a plant from this symbiosis is made under low phosphate availability, and exactly under these conditions, SLs are exudated in an increased amount [91,97].

These findings were the basic foundation for Kretzschmar and colleagues to search for involved $A B C$ transporters, more exactly the group of PDR transporters. PDRs are often found in roots [98], 


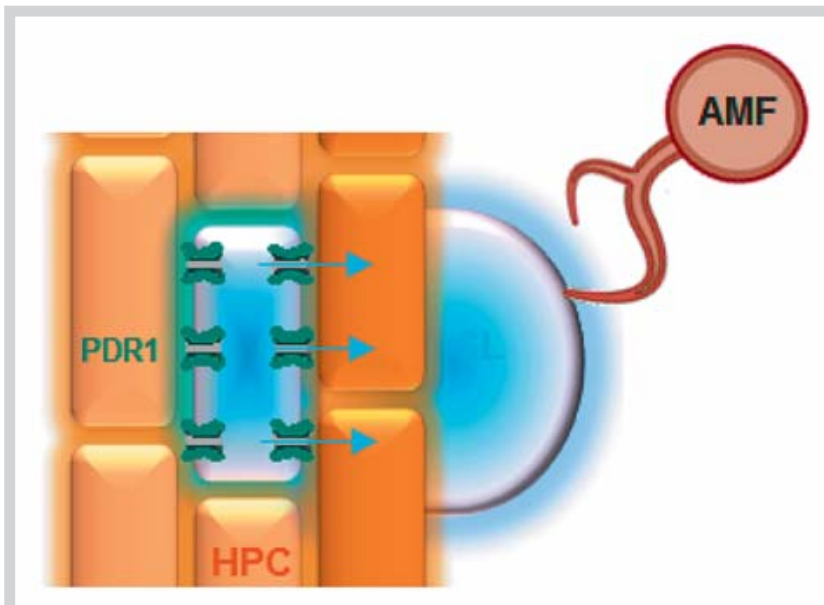

Fig. 9 PDR1-mediated strigolactones exudation from hypodermal passage cells (HPC) into the rhizosphere to enable an interaction with arbuscular mycorrhizal fungi (AMF). Adapted from Kretzschmar et al. [99] (see also Supporting Information). (Color figure available online only.)

and the activity of one PDR member, AtABCG30 (PDR2 in A. thaliana), is known to affect the soil microbial community [19]. There is also evidence of their affinity for compounds structurally related to SLs [99].

Six primary candidates were chosen and investigated for expression levels in roots under different phosphate concentrations or the amount of AMF colonization. This approach led to the discovery of an ABCG transporter, PDR1 in P. hybrida, the first protein associated with SL cell export [99]. The plasma membrane localization of PDR1 was confirmed through the fusion with GFP. The need for transport of a signalling molecule relevant for arbuscular mycorrhizal symbiosis was proven by the comparison of mutant and wild-type plants. The final conclusion is that PDR1 mediates the SL export from hypodermal passage cells into the rhizosphere (๑ Fig. 9).

Apart from these findings, there is also evidence of SL transport through the xylem from the root, where SLs are mainly synthesized, to the shoot [100]. The required transport system remains unclear, which raises the question whether other $A B C$ transporters could be involved in loading and unloading the SLs to and from the xylem.

\section{Elucidation of the structure of a strigolactone transporter}

The field of plant hormones and their transport is steadily expanding, and there is an urgent need for an understanding of the molecular basis of substrate and inhibitor interactions.

Yang and Murphy developed structural models of AtABCB4 and AtABCB19 in a comparative study of the auxin transporters PIN, ABCB (PGP), and AUX/LAX [101]. The bacterial ABC transporter Sav1866 served as a template for the models. Their results indicate that AtABCB4 has three binding sites for IAA, whereas AtABCB19 has only two. This might be due to the different transport directions, as AtABCB4 can act as an importer and exporter, whereas AtABCB19 is only an exporter.

As already mentioned in the auxin transport section, a more extensive modelling approach was published in 2012. The structures of AtABCB1, AtABCB4, AtABCB19, and AtABCB14 (in this study considered as a non-auxin transporter) were explored by

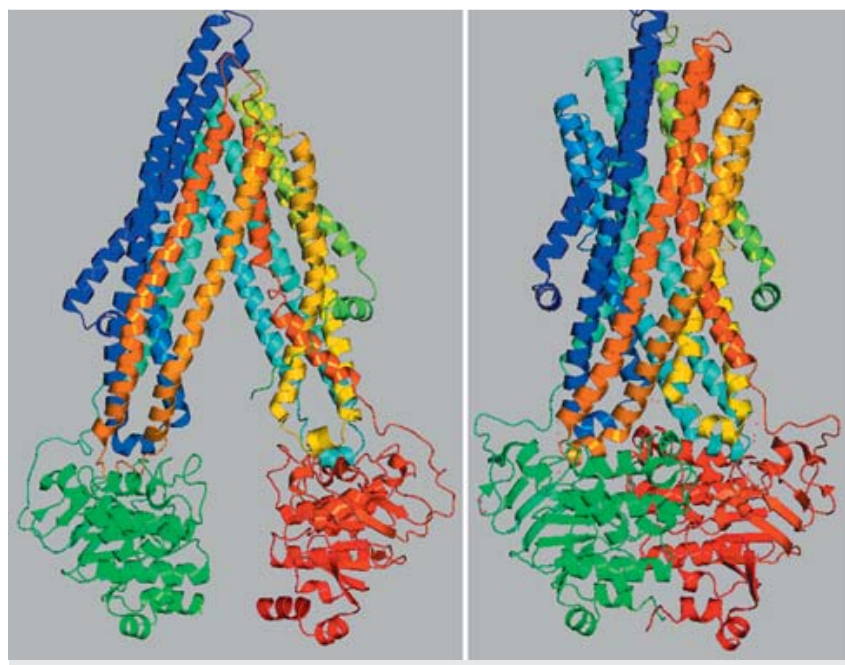

Fig. 10 MmABCB1 open state, Sav1866 closed state. (Color figure available online only.)

the development of homology models. Analysis of the models led to the hypothesis that the mammalian and plant $A B C B$ transporters separated very early during evolution according to the structures of their binding sites [65]. MmABCB1 (Mus musculus P-glycoprotein, 3G5 U [102]) was used as a template for the open state and Sav1866 (Staphylococcus aureus, 2HYD [102]) for the closed state models ( $\odot$ Fig. 10 ).

The models indicate that $\mathrm{ABCB}$ family members have characteristic translocation chambers in mammals and in plants. Docking studies improved the understanding of the relationships between the transport processes and the binding sites, and shed light into the substrate specificity and translocation mechanisms. This work could provide a basis for future research aimed at a structure-based design of inhibitors. However, it is worth mentioning that Kaneda et al. found AtABCB14 to be an auxin transporter, too [50].

A very similar approach was used in our group to elucidate the structure of the already mentioned PDR1 transporter in $P$. hybrida, which acts as an SL transporter. While all the previously modelled plant $A B C$ transporters belong to the $A B C B$ subfamily, PhPDR1 belongs to the ABCG subfamily, which exhibits a reverse topology to the other $\mathrm{ABC}$ transporters ( $\odot$ Fig. 11). For this kind of protein, not a single crystal structure has been solved up to now, so finding a proper template is a challenging task.

Recently, Rutledge et al. published an exhaustive modelling approach for exploring the 3D structure of PDR5 in Saccharomyces cerevisiae. The TMD of Sav1866 and the NBD of hemolysin B were used as templates for the model in its open-to-out conformation. For the open to in state, they used the mouse Pgp structure [103]. The workflow we chose for our studies is strongly based on this work.

At first, the TMDs had to be defined. The knowledge about helix localizations in plant transporters is scant. Thus, the Uniprot database [104] indicates different numbers of transmembrane helices (between 12 for AtABCG30 to 14 for NtPDR1), and no information at all for the protein of interest, PhPDR1. The previously modelled plant transporters had the topologies of their particular templates, which means 6 helices - NBD - 6 helices - NBD for the $A B C B$ subfamily. In our case the topology is not yet investi- 


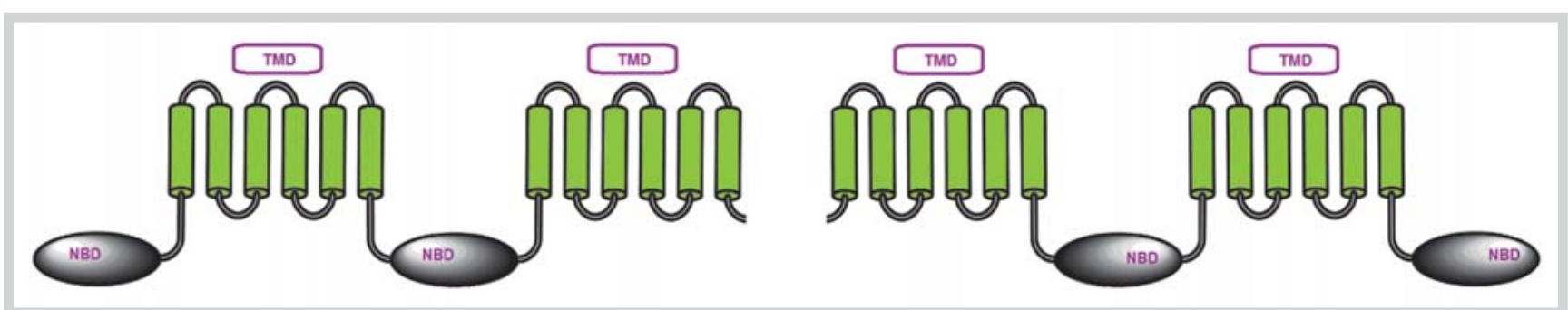

Fig. 11 Reverse topology of pleiotropic drug resistance transporters (left) in comparison to a regular topology (right). (Color figure available online only.)

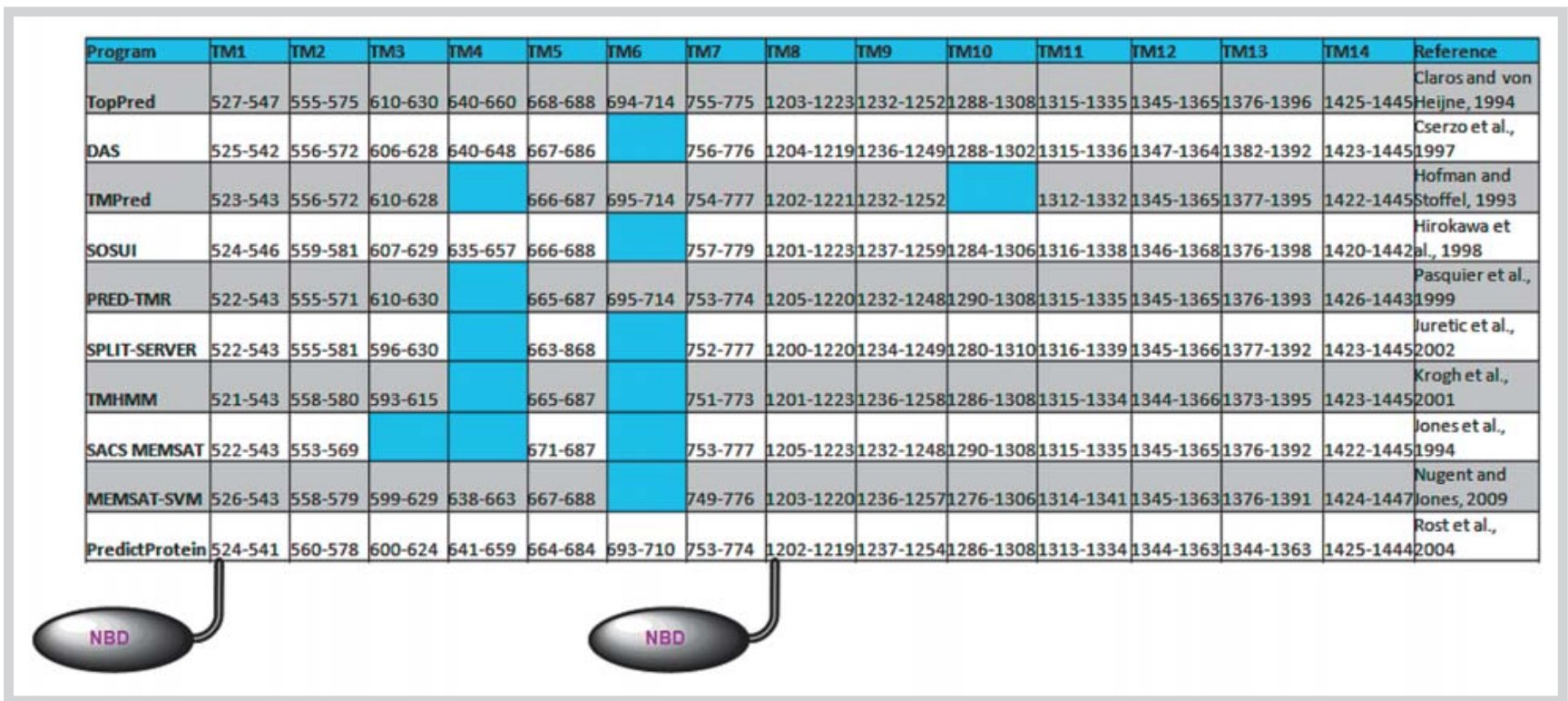

Fig. 12 Overview of tools and the predicted helix sections. (Color figure available online only.)

gated, and there is no template with a reverse topology available. Hence, we used several different software packages for predicting transmembrane helices and compared the predictions (๑ Fig. 12) [105-114].

The different packages for predicting the secondary structure disagreed for a few helices, some predicting 13 or only 11 transmembrane helices. However, an odd number of helices implies that the $\mathrm{N}$ - and $\mathrm{C}$-terminal ends are on different sides of the membrane, which seems quite unlikely for $A B C$ transporters. In a next step, a multiple sequence alignment (MSA) of 11 sequences from plant, bacterial, and mammalian $\mathrm{ABC}$ transporters combining the current knowledge of transporter topologies was used to assign the missing helices, following the hypothesis of the common $6+6$ topology.

The final choice of the template was based on an MSA with the potential templates ( Fig. 13), including crystallized ABC transporters reported in the Protein Data Bank (PDB) [102] and the high-quality, reliably validated homology model of Pdr5 in S. cerevisiae. The latter was already used as a template to model the 3D structure of Cdr1 in Candida albicans (Rawal et al., 2013). As can be seen in 0 Fig. 13, PDR5 shows the highest sequence identity percentage and was thus chosen as a template for further comparative modelling steps.

PDR5 and PDR1 were aligned pairwise in MOE [115], and the result was manually edited to align the respective predicted trans- membrane helices. Gaps were allowed in the least conserved loop regions to accommodate for those changes. The final alignment (Figs. 15 and 2S, Supporting Information) with 24.9\% overall identity of the whole sequence (TMD1 26.4\%/NBD1 22.2\%/TMD2 $13.4 \% / N B D 234.1 \%$ ) was used as an input for Modeller 9.12 [116] to create ten models of the open-to-in conformation.

Modeller provides three validation scores: molpdf, the DOPE score (discrete optimized protein energy), and the GA341 score. According to these, the best three models were chosen for further validation. Using the Ramachandran plots and the G-factors computed using PROCHECK [117] on PDBsum [118], a final model with $91.2 \%$ and $88.9 \%$ of the amino acids in the most favored regions, respectively, for TMD1 and TMD2, as well as a G-factor of -0.01 and -0.16 for TMD1 and TMD2, was selected ( $\bullet$ Fig. 14) [119].

We further validated the model by comparing the respective positions of the proline residues in both the template and the model. Proline can cause transmembrane helix breaks or kinks. Therefore, proper alignment of these residues is required for a coherent helical geometry in the model. In the case of our model, no mismatches of prolines between template and target structure occurred.

Finally, the localizations of charged residues were investigated to assure that they do not point towards the membrane (O Fig. 15). 


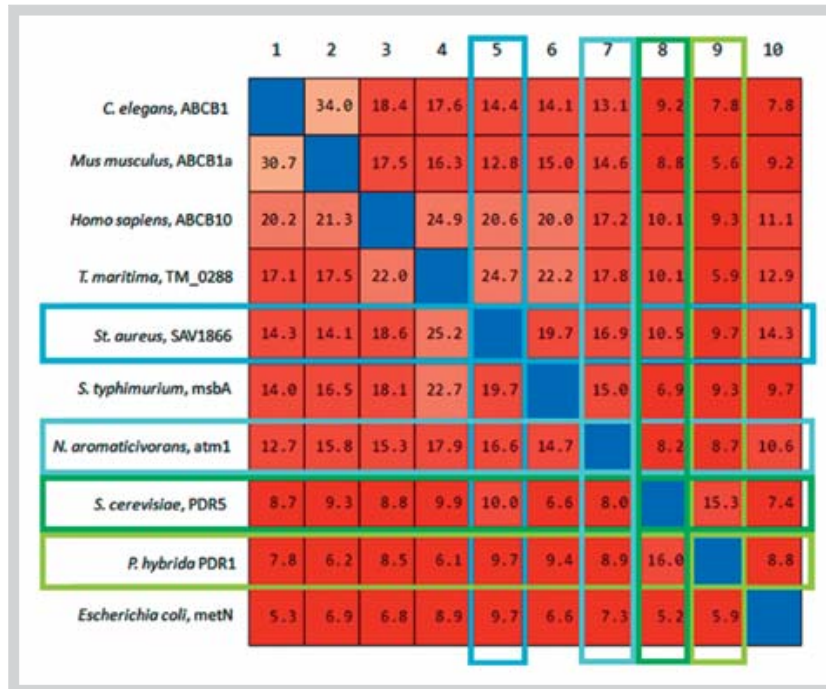

Fig. 13 Identity percentage matrix derived from the multiple sequence alignment of the possible templates with PhPDR1. PDR5 has the highest identity percentage [115]. (Color figure available online only.)

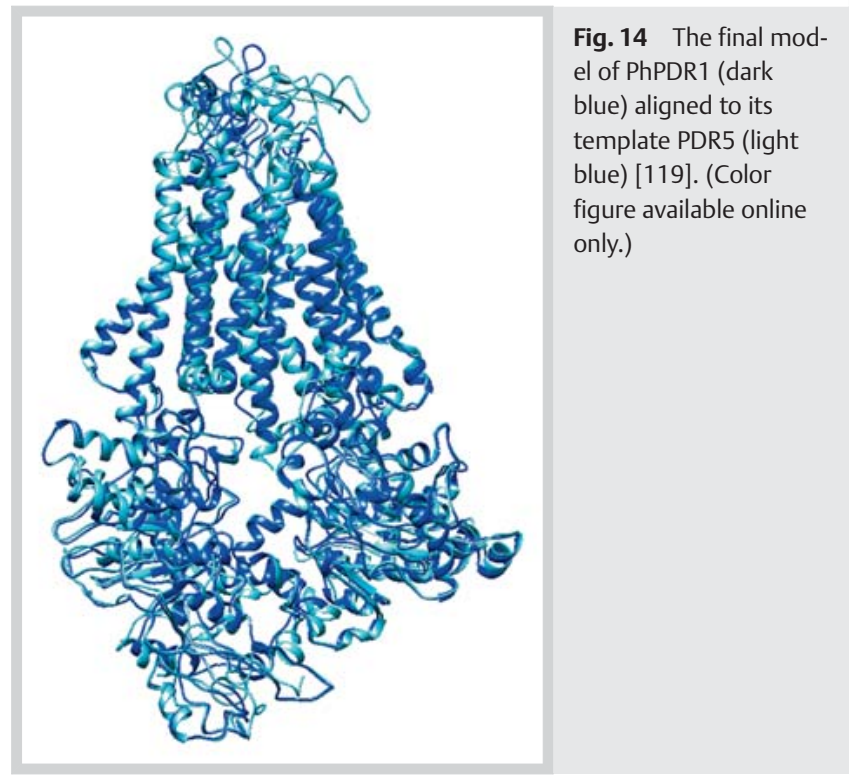

Fig. 14 The final modfigure available online only.)

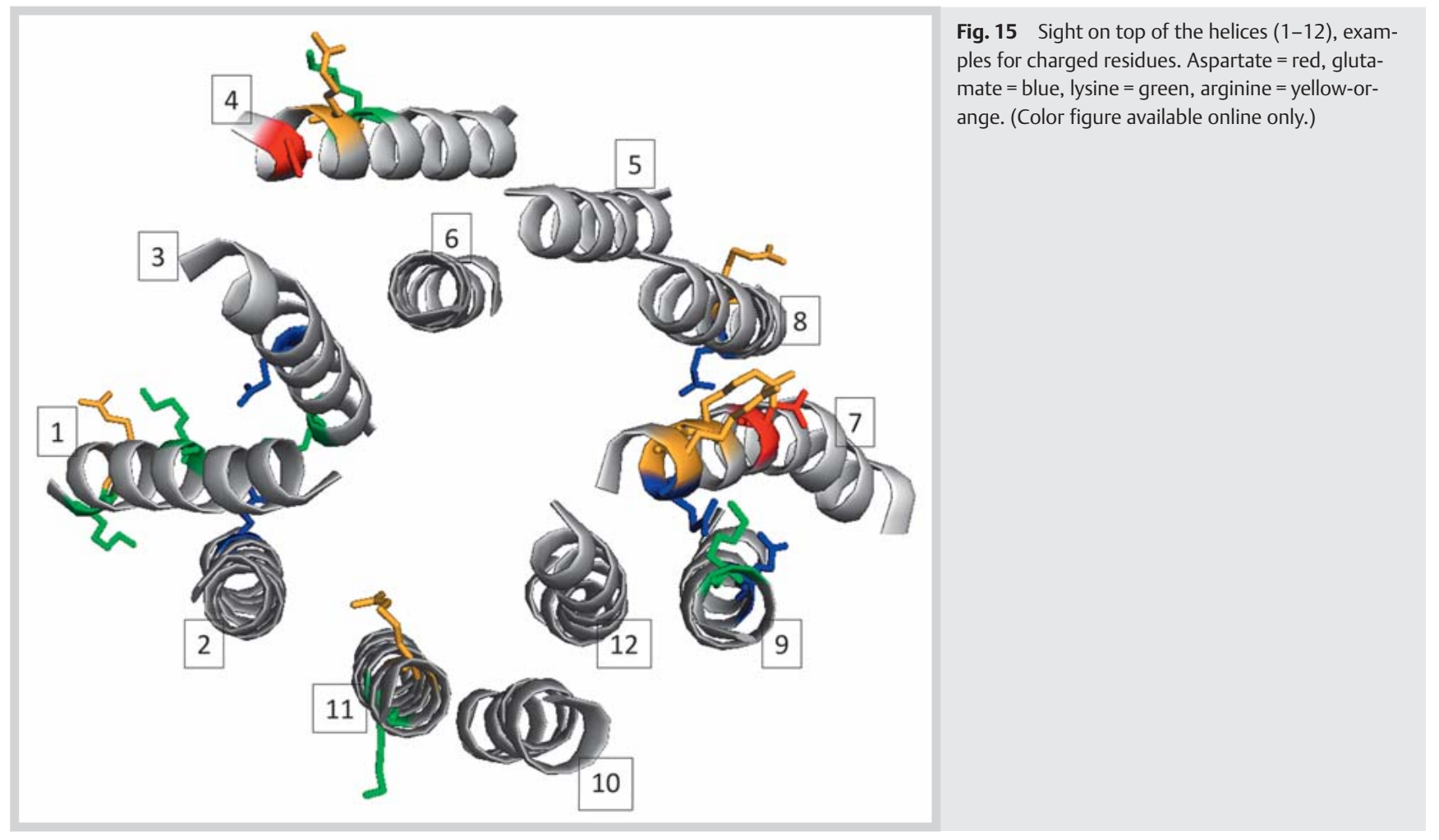

As $\odot$ Fig. 15 shows, the charged residues in helices 2, 5, 6, 9, 10 , and 12 fit perfectly to their environments. To show how the others are embedded, they are presented from different views in - Fig. 16.

Lysine 517 and arginine 518 are on the very bottom of helix 1, so they might interact with the hydrophilic parts of the phospholipids. Lysine 526 and glutamate 615 probably form a hydrogen bond ( Fig. 16A). Aspartate 628 and arginine 635 might also interact with phospholipid head groups, whereas lysine 638 is directly pointing towards the membrane ( Fig. 16B), which is quite unlikely. In helix 7, glutamate 1225 and arginine 1226 are again near the top of the membrane, while the orientation of aspartate 1219 is also pointing towards the lipophilic part of the membrane. Arginine 1260 is close to the bottom of helix 8 ( Fig. 16C) and might also exhibit a different rotamer. Lysine 1365 is localized on the outer surface of the protein, a hydrophilic interaction on top here is conceivable, too ( Fig. 16D). Thus, this analysis shows that a few charged amino acids need in-depth analysis and that the model requires some modifications in these regions. 


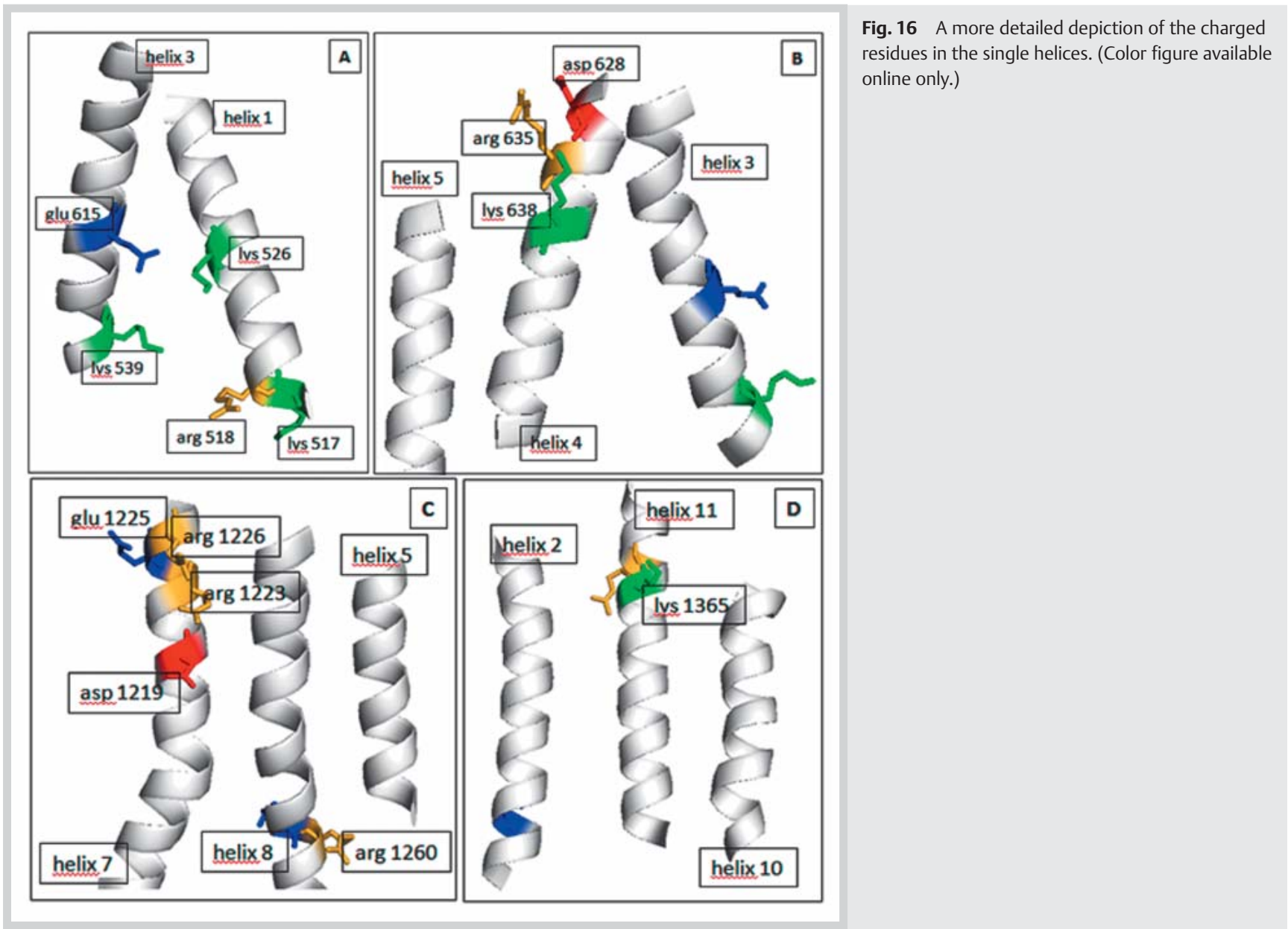

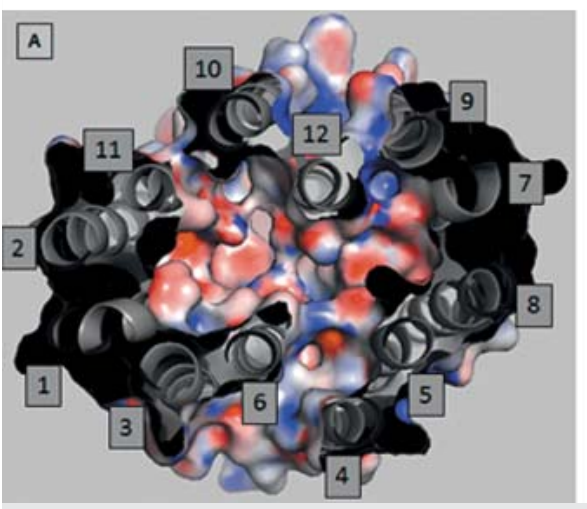

Fig. 17 Insight into the translocation chambers of AtABCB1 (A), PhPDR1 (B), and PDR5 in Saccharomyces cervisiae from the bottom view of the trans-
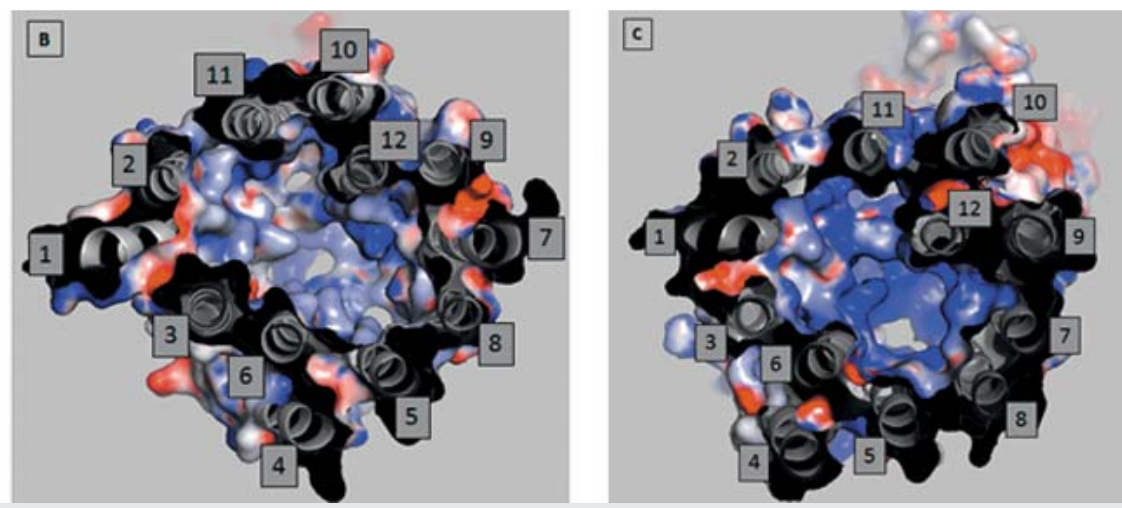

membrane domains (numbered from 1-12). Isosurface colors: red = negative, white $=$ neutral, blue $=$ positive [120]. (Color figure available online only. $)$
Finally, the electrostatic potentials of the model were investigated in PyMOL [120] to characterize the translocation chamber. The surface was compared with those of the template PDR5 and AtABCB1. As mentioned before, AtABCB1 is an auxin transporter and shows a very mixed electrostatic potential surface in the translocation chamber ( Fig. 17 A), whereas PDR5 forms a positive isosurface ( $\odot$ Fig. 17C). PhPDR1 represents a rather neutral, leaning to positive translocation chamber ( $\bullet$ Fig. 17B).
After these first investigations, this model could now serve as starting point for further studies, such as molecular dynamics simulations and docking of SL analogs.

\section{Conclusions and Outlook}

$\nabla$

The understanding of the molecular basis of transport across cellular membranes and its modulation by small molecules becomes increasingly important. In this article, we present an overview 
about the currently known $A B C$ transporters in plants including their hitherto discovered functions such as detoxification, symbiosis and rhizosphere communication, metabolite transport, and protection against exogene dangers. Special attention was put on the translocation of phytohormones, including auxins, abscisic acid, cytokinins, and strigolactones. Although most of the hormones have been known for a long time and some of the transport processes are well defined, a molecular understanding of the transport process is still missing. Although our knowledge of transmembrane transport proteins grows constantly, the complexity of these sophisticated systems should not be underestimated. Nevertheless, the recently published X-ray structures of bacterial and mammalian $A B C$ transporters allow for the development of comparative protein models of their plant analogs, which aid in the understanding of their structure and function. To demonstrate the usefulness of this approach, we built a homology model of PhPDR1, a strigolactone transporter from P. hybrida. These 3D models are a promising basis for future research as they offer the possibility to explore binding sites, discover potential substrates and inhibitors, and to understand their interactions with the protein. This definitely will also pave the way for the discovery of new agrochemicals.

\section{Supporting information}

The pairwise alignment of PDR5 and PDR1, which was used as input for Modeller [116] to calculate the models, is available as Supporting Information.

\section{Acknowledgements}

$\nabla$

We gratefully acknowledge financial support provided by the Austrian Science Fund, grant F3502 as well as by the doctoral college Biopromotion by the University of Vienna.

\section{Conflict of Interest}

$\nabla$

The authors declare no conflict of interest.

\section{References}

1 Kang J, Park J, Choi H, Burla B, Kretzschmar T, Lee Y, Martinoia E. Plant ABC Transporters. Arabidopsis Book 2011; 9: e0153

2 Robert HS, Friml J. Auxin and other signals on the move in plants. Nat Chem Biol 2009; 5: 325-332

3 Santner A, Estelle M. Recent advances and emerging trends in plant hormone signalling. Nature 2009; 459: 1071-1078

4 Kretzschmar T, Burla B, Lee Y, Martinoia E, Nagy R. Functions of ABC transporters in plants. Essays Biochem 2011; 50: 145-160

5 Martinoia E, Grill E, Tommasini R, Kreuz K, Amrhein N. ATP-dependent glutathione S-conjugate "export" pump in the vacuolar membrane of plants. Nature 1993; 364: 247-249

$6 \mathrm{Lu}$ YP, Li ZS, Rea PA. AtMRP1 gene of Arabidopsis encodes a glutathione S-conjugate pump: isolation and functional definition of a plant ATPbinding cassette transporter gene. Proc Natl Acad Sci U S A 1997; 94: 8243-8248

7 Lu YP, Li ZS, Drozdowicz YM, Hortensteiner S, Martinoia E, Rea PA. AtMRP2, an Arabidopsis ATP binding cassette transporter able to transport glutathione S-conjugates and chlorophyll catabolites: functional comparisons with Atmrp1. Plant Cell 1998; 10: 267-282

8 Tommasini R, Vogt E, Fromenteau M, Hörtensteiner S, Matile P, Amrhein $N$, Martinoia E. An ABC-transporter of Arabidopsis thaliana has both glutathione-conjugate and chlorophyll catabolite transport activity. Plant J 1998; 13: 773-780
9 Kim DY, Bovet L, Maeshima M, Martinoia E, Lee Y. The ABC transporter AtPDR8 is a cadmium extrusion pump conferring heavy metal resistance. Plant J 2007; 50: 207-218

10 Lee M, Lee K, Lee J, Noh EW, Lee Y. AtPDR12 contributes to lead resistance in Arabidopsis. Plant Physiol 2005; 138: 827-836

11 Mackenzie B, Takanaga H, Hubert N, Rolfs A, Hediger MA. Functional properties of multiple isoforms of human divalent metal-ion transporter 1 (DMT1). Biochem J 2007; 403: 59-69

12 Larsen PB, Geisler MJB, Jones CA, Williams KM, Cancel JD. ALS3 encodes a phloem-localized $A B C$ transporter-like protein that is required for aluminum tolerance in Arabidopsis. Plant J 2005; 41: 353-363

13 Larsen PB, Cancel J, Rounds M, Ochoa V. Arabidopsis ALS1 encodes a root tip and stele localized half type $A B C$ transporter required for root growth in an aluminum toxic environment. Planta 2007; 225: 14471458

14 Prell J, Poole P. Metabolic changes of Rhizobia in legume nodules. Trends Microbiol 2006; 14: 161-168

15 Sugiyama A, Shitan N, Yazaki K. Involvement of a soybean ATP-binding cassette-type transporter in the secretion of genistein, a signal flavonoid in legume-Rhizobium symbiosis. Plant Physiol 2007; 144: 20002008

16 Sugiyama A, Shitan N, Yazaki K. Signaling from soybean roots to Rhizobium: An ATP-binding cassette-type transporter mediates genistein secretion. Plant Signal Behav 2008; 3: 38-40

17 Priha 0 , Grayston SJ, Pennanen T, Smolander A. Microbial activities related to $\mathrm{C}$ and $\mathrm{N}$ cycling and microbial community structure in the rhizospheres of Pinus sylvestris, Picea abies and Betula pendula seedlings in an organic and mineral soil. FEMS Microbiol Ecol 1999; 30: 187-199

18 Mougel C, Offre P, Ranjard L, Corberand T, Gamalero E, Robin C, Lemanceau $P$. Dynamic of the genetic structure of bacterial and fungal communities at different developmental stages of Medicago truncatula Gaertn. cv. Jemalong line J5. New Phytol 2006; 170: 165-175

19 Badri DV, Quintana N, El Kassis EG, Kim HK, Choi YH, Sugiyama A, Verpoorte R, Martinoia E, Manter DK, Vivanco JM. An ABC transporter mutation alters root exudation of phytochemicals that provoke an overhaul of natural soil microbiota. Plant Physiol 2009; 151: 2006-2017

20 Noctor G, Foyer $\mathrm{CH}$. Ascorbate and Glutathione: Keeping Active Oxygen Under Control. Annu Rev Plant Physiol Plant Mol Biol 1998; 49: 249279

21 Hinder B, Schellenberg M, Rodoni S, Ginsburg S, Vogt E, Martinoia E, Matile P, Hörtensteiner S. How plants dispose of chlorophyll catabolites. Directly energized uptake of tetrapyrrolic breakdown products into isolated vacuoles. J Biol Chem 1996; 271: 27233-27236

22 Nagy R, Grob H, Weder B, Green P, Klein M, Frelet-Barrand A, Schjoerring $J K$, Brearley C, Martinoia E. The Arabidopsis ATP-binding cassette protein AtMRP5/AtABCC5 is a high affinity inositol hexakisphosphate transporter involved in guard cell signaling and phytate storage. J Biol Chem 2009; 284: 33614-33622

23 Zolman BK, Silva ID, Bartel B. The Arabidopsis pxa1 mutant is defective in an ATP-binding cassette transporter-like protein required for peroxisomal fatty acid beta-oxidation. Plant Physiol 2001; 127: 1266-1278

24 Yazaki K, Shitan N, Takamatsu H, Ueda K, Sato F. A novel Coptis japonica multidrug-resistant protein preferentially expressed in the alkaloidaccumulating rhizome. J Exp Bot 2001; 52: 877-879

25 Shitan N, Bazin I, Dan K, Obata K, Kigawa K, Ueda K, Sato F, Forestier C, Yazaki K. Involvement of CjMDR1, a plant multidrug-resistance-type ATP-binding cassette protein, in alkaloid transport in Coptis japonica. Proc Natl Acad Sci U S A 2003; 100: 751-756

26 Sato F, Takeshita N, Fitchen JH, Fujiwara H, Yamada Y. S-adenosyl-1-methionine: scoulerine-9-0-methyltransferase from cultured Coptis japonica cells. Phytochemistry 1993; 32: 659-664

27 Badri DV, Loyola-Vargas VM, Broeckling CD, De-la-Peña C, Jasinski M, Santelia D, Martinoia E, Sumner LW, Banta LM, Stermitz F, Vivanco JM. Altered profile of secondary metabolites in the root exudates of Arabidopsis ATP-binding cassette transporter mutants. Plant Physiol 2008; 146: $762-771$

28 Bultreys A, Trombik T, Drozak A, Boutry M. Nicotiana plumbaginifolia plants silenced for the ATP-binding cassette transporter gene NpPDR1 show increased susceptibility to a group of fungal and oomycete pathogens. Mol Plant Pathol 2009; 10: 651-663

29 Kobae Y, Sekino T, Yoshioka H, Nakagawa T, Martinoia E, Maeshima M. Loss of AtPDR8, a plasma membrane ABC transporter of Arabidopsis thaliana, causes hypersensitive cell death upon pathogen infection. Plant Cell Physiol 2006; 47: 309-318 
30 Campbell EJ, Schenk PM, Kazan K, Penninckx IAMA, Anderson JP, Maclean DJ, Cammue BPA, Ebert PR, Manners JM. Pathogen-responsive expression of a putative ATP-binding cassette transporter gene conferring resistance to the diterpenoid sclareol is regulated by multiple defense signaling pathways in Arabidopsis. Plant Physiol 2003; 133: 1272-1284

31 Bessire M, Borel S, Fabre G, Carraça L, Efremova N, Yephremov A, Cao Y, Jetter R, Jacquat AC, Métraux JP, Nawrath C. A member of the Pleiotropic Drug Resistance family of ATP binding cassette transporters is required for the formation of a functional cuticle in Arabidopsis. Plant Cell 2011; 23: $1958-1970$

32 Panikashvili D, Savaldi-Goldstein S, Mandel T, Yifhar T, Franke RB, Höfer $R$, Schreiber L, Chory J, Aharoni A. The Arabidopsis DESPERADO/ AtWBC11 transporter is required for cutin and wax secretion. Plant Physiol 2007; 145: 1345-1360

33 Pighin JA, Zheng H, Balakshin LJ, Goodman IP, Western TL, Jetter R, Kunst $L$, Samuels AL. Plant cuticular lipid export requires an $A B C$ transporter. Science 2004; 306: 702-704

34 Jasiński M, Stukkens Y, Degand H, Purnelle B, Marchand-Brynaert J, Boutry $M$. A plant plasma membrane ATP binding cassette-type transporter is involved in antifungal terpenoid secretion. Plant Cell 2001; 13: $1095-1107$

35 Cushnie TPT, Lamb AJ. Recent advances in understanding the antibacterial properties of flavonoids. Int J Antimicrob Agents 2011; 38: 99-107

36 Jia Z, Zou B, Wang X, Qiu J, Ma H, Gou Z, Song S, Dong H. Quercetin-induced $\mathrm{H}(2) \mathrm{O}(2)$ mediates the pathogen resistance against Pseudomonas syringae pv. Tomato DC3000 in Arabidopsis thaliana. Biochem Biophys Res Commun 2010; 396: 522-527

37 Banasiak J, Biala W, Staszków A, Swarcewicz B, Kepczynska E, Figlerowicz $M$, Jasinski M. A Medicago truncatula $\mathrm{ABC}$ transporter belonging to subfamily G modulates the level of isoflavonoids. J Exp Bot 2013; 64: 1005-1015

38 Okada K, Shimura Y. Modulation of root growth by physical stimuli. In: Meyerowitz EM, Somerville CR. Arabidopsis. Cold Spring Harbor: Laboratory Press; 1994: 665-684

39 Scarpella E, Marcos D, Friml J, Berleth T. Control of leaf vascular patterning by polar auxin transport. Genes Dev 2006; 20: 1015-1027

40 Cosgrove DJ. Growth of the plant cell wall. Nat Rev Mol Cell Biol 2005; 6: 850-861

41 Bonner J, Bandurski RS. Studies of the physiology, pharmacology, and biochemistry of the auxins. Annu Rev Plant Physiol 1952; 3: 59-86

42 Whippo CW, Hangarter RP. Phototropism: bending towards enlightenment. Plant Cell 2006; 18: 1110-1119

43 Marchant A, Kargul J, May ST, Muller P, Delbarre A, Perrot-Rechenmann C, Bennett MJ. AUX1 regulates root gravitropism in Arabidopsis by facilitating auxin uptake within root apical tissues. EMBO J 1999; 18: 20662073

44 Blakeslee JJ, Peer WA, Murphy AS. Auxin transport. Curr Opin Plant Biol 2005; 8: 494-500

45 Kramer EM, Bennett MJ. Auxin transport: a field in flux. Trends Plant Sci 2006; 11: 382-386

46 Morris DA, Rubery PH, Jarman J, Sabater M. Effects of inhibitors of protein synthesis on transmembrane auxin transport in Cucurbita pepo $\mathrm{L}$. hypocotyl segments. J Exp Bot 1991; 42: 773-783

47 Petrásek J, Mravec J, Bouchard R, Blakeslee JJ, Abas M, Seifertová D, Wisniewska J, Tadele Z, Kubes M, Covanová M, Dhonukshe P, Skupa P, Benková E, Perry L, Krecek P, Lee OR, Fink GR, Geisler M, Murphy AS, Luschnig C, Zazímalová E, Friml J. PIN proteins perform a rate-limiting function in cellular auxin efflux. Science 2006; 312: 914-918

48 Geisler M, Blakeslee JJ, Bouchard R, Lee OR, Vincenzetti V, Bandyopadhyay A, Titapiwatanakun B, Peer WA, Bailly A, Richards EL, Ejendal KFK, Smith AP, Baroux C, Grossniklaus U, Müller A, Hrycyna CA, Dudler R, Murphy AS, Martinoia E. Cellular efflux of auxin catalyzed by the Arabidopsis MDR/PGP transporter AtPGP1. Plant J 2005; 44: 179-194

49 Cho M, Lee SH, Cho HT. P-glycoprotein4 displays auxin efflux transporter-like action in Arabidopsis root hair cells and tobacco cells. Plant Cell 2007; 19: 3930-3943

50 Kaneda M, Schuetz M, Lin BSP, Chanis C, Hamberger B, Western TL, Ehlting J, Samuels AL. ABC transporters coordinately expressed during lignification of Arabidopsis stems include a set of $A B C B$ s associated with auxin transport. J Exp Bot 2011; 62: 2063-2077

51 Titapiwatanakun B, Blakeslee JJ, Bandyopadhyay A, Yang H, Mravec J, Sauer M, Cheng Y, Adamec J, Nagashima A, Geisler M, Sakai T, Friml J, Peer WA, Murphy AS. ABCB19/PGP19 stabilises PIN1 in membrane microdomains in Arabidopsis. Plant J 2009; 57: 27-44
52 Bouchard R, Bailly A, Blakeslee IJ, Oehring SC, Vincenzetti V, Lee OR, Paponov I, Palme K, Mancuso S, Murphy AS, Schulz B, Geisler M. Immunophilin-like TWISTED DWARF1 modulates auxin efflux activities of Arabidopsis P-glycoproteins. J Biol Chem 2006; 281: 30603-30612

53 Bailly A, Sovero V, Vincenzetti V, Santelia D, Bartnik D, Koenig BW, Mancuso S, Martinoia E, Geisler M. Modulation of P-glycoproteins by auxin transport inhibitors is mediated by interaction with immunophilins. J Biol Chem 2008; 283: 21817-21826

54 Christie JM, Yang H, Richter GL, Sullivan S, Thomson CE, Lin J, Titapiwatanakun B, Ennis M, Kaiserli E, Lee OR, Adamec J, Peer WA, Murphy AS. phot1 inhibition of ABCB19 primes lateral auxin fluxes in the shoot apex required for phototropism. PLoS Biol 2011; 9: e1001076

55 Henrichs S, Wang B, Fukao Y, Zhu J, Charrier L, Bailly A, Oehring SC, Linnert M, Weiwad M, Endler A, Nanni P, Pollmann S, Mancuso S, Schulz A, Geisler M. Regulation of ABCB1/PGP1-catalysed auxin transport by linker phosphorylation. EMBO J 2012; 31: 2965-2980

56 Katekar GF. Inhibitors of the geotropic response in plants: a correlation of molecular structures. Phytochemistry 1976; 15: 1421-1424

57 Katekar GF, Geissler AE. Auxin Transport Inhibitors: IV. Evidence of a common mode of action for a proposed class of auxin transport inhibitors: the phytotropins. Plant Physiol 1980; 66: 1190-1195

58 Nagashima A, Uehara Y, Sakai $T$. The ABC subfamily B auxin transporter AtABCB19 is involved in the inhibitory effects of N-1-naphthyphthalamic acid on the phototropic and gravitropic responses of Arabidopsis hypocotyls. Plant Cell Physiol 2008; 49: 1250-1255

59 Lewis DR, Miller ND, Splitt BL, Wu G, Spalding EP. Separating the roles of acropetal and basipetal auxin transport on gravitropism with mutations in two Arabidopsis multidrug resistance-like ABC transporter genes. Plant Cell 2007; 19: 1838-1850

60 Kim JY, Henrichs S, Bailly A, Vincenzetti V, Sovero V, Mancuso S, Pollmann S, Kim D, Geisler M, Nam HG. Identification of an ABCB/P-glycoproteinspecific inhibitor of auxin transport by chemical genomics. J Biol Chem 2010; 285: 23309-23317

61 Surpin M, Rojas-Pierce M, Carter C, Hicks GR, Vasquez J, Raikhel NV. The power of chemical genomics to study the link between endomembrane system components and the gravitropic response. Proc Natl Acad Sci U S A 2005; 102: 4902-4907

62 Rojas-Pierce M, Titapiwatanakun B, Sohn EJ, Fang F, Larive CK, Blakeslee J, Cheng Y, Cutler SR, Cuttler S, Peer WA, Murphy AS, Raikhel NV. Arabidopsis P-glycoprotein19 participates in the inhibition of gravitropism by gravacin. Chem Biol 2007; 14: 1366-1376

63 Conseil G, Baubichon-Cortay H, Dayan G, Jault JM, Barron D, Di Pietro A. Flavonoids: a class of modulators with bifunctional interactions at vicinal ATP- and steroid-binding sites on mouse P-glycoprotein. Proc Natl Acad Sci U S A 1998; 95: 9831-9836

64 Jacobs $M$, Rubery $P H$. Naturally occurring auxin transport regulators. Science 1988; 241: 346-349

65 Bailly A, Yang H, Martinoia E, Geisler M, Murphy AS. Plant lessons: exploring $\mathrm{ABCB}$ functionality through structural modeling. Front Plant Sci 2012; 2: 108

66 Aller SG, Yu J, Ward A, Weng Y, Chittaboina S, Zhuo R, Harrell PM, Trinh $Y T$, Zhang $Q$ Urbatsch IL, Chang G. Structure of P-glycoprotein reveals a molecular basis for poly-specific drug binding. Science 2009; 323: 1718-1722

67 Groot SP, Karssen CM. Dormancy and germination of abscisic acid-deficient tomato seeds: studies with the sitiens mutant. Plant Physiol 1992; 99: 952-958

68 Marshall JG, Scarratt JB, Dumbroff EB. Induction of drought resistance by abscisic acid and paclobutrazol in jack pine. Tree Physiol 1991; 8: $415-421$

69 Saeedipour S. Salinity tolerance of rice lines related to endogenous abscisic acid (ABA) level synthesis under stress. AJPS 2011; 5: 628-633

70 Finkelstein RR, Gampala SSL, Rock CD. Abscisic acid signaling in seeds and seedlings. Plant Cell 2002; 14 (Suppl. 1): S15-S45

71 Okamoto M, Hanada A, Kamiya Y, Yamaguchi S, Nambara E. Measurement of abscisic acid and gibberellins by gas chromatography/mass spectrometry. Methods Mol Biol 2009; 495: 53-60

72 Kuromori T, Miyaji T, Yabuuchi H, Shimizu H, Sugimoto E, Kamiya A Moriyama Y, Shinozaki K. ABC transporter AtABCG25 is involved in abscisic acid transport and responses. Proc Natl Acad Sci U S A 2010; 107: 2361-2366

73 Koiwai H, Nakaminami K, Seo M, Mitsuhashi W, Toyomasu T, Koshiba T. Tissue-specific localization of an abscisic acid biosynthetic enzyme, AAO3, in Arabidopsis. Plant Physiol 2004; 134: 1697-1707 
74 Schachtman DP, Goodger JQD. Chemical root to shoot signaling under drought. Trends Plant Sci 2008; 13: 281-287

75 Kang J, Hwang JU, Lee M, Kim YY, Assmann SM, Martinoia E, Lee Y. PDRtype $A B C$ transporter mediates cellular uptake of the phytohormone abscisic acid. Proc Natl Acad Sci U S A 2010; 107: 2355-2360

76 Kuromori T, Sugimoto E, Shinozaki K. Intertissue signal transfer of abscisic acid from vascular cells to guard cells. Plant Physiol 2014; 164: $1587-1592$

77 Kuromori T, Sugimoto E, Shinozaki K. Arabidopsis mutants of AtABCG22, an $A B C$ transporter gene, increase water transpiration and drought susceptibility. Plant J 2011; 67: 885-894

78 Gan S, Amasino RM. Inhibition of leaf senescence by autoregulated production of cytokinin. Science 1995; 270: 1986-1988

79 Werner T, Motyka V, Strnad M, Schmülling T. Regulation of plant growth by cytokinin. PNAS 2001; 98: 10487-10492

80 Samuelson ME, Larsson CM. Nitrate regulation of zeatin riboside levels in barley roots: effects of inhibitors of $\mathrm{N}$ assimilation and comparison with ammonium. Plant Science 1993; 93: 77-84

81 Sakakibara H. Cytokinins: activity, biosynthesis, and translocation. Annu Rev Plant Biol 2006; 57: 431-449

82 Chory J, Reinecke D, Sim S, Washburn T, Brenner M. A role for cytokinins in de-etiolation in Arabidopsis (det mutants have an altered response to cytokinins). Plant Physiol 1994; 104: 339-347

83 George EF, Hall MA, Klerk GJD. Plant growth regulators II: Cytokinins, their analogues and antagonists. In: George EF, Hall MA, Klerk GJD, editors. Plant propagation by tissue culture. Amsterdam: Springer; 2008: 205-226

84 Barciszewski J, Siboska GE, Pedersen BO, Clark BFC, Rattan SIS. Evidence for the presence of kinetin in DNA and cell extracts. FEBS Letters 1996; 393: $197-200$

85 Skoog F, Armstrong DJ. Cytokinins. Annu Rev Plant Physiol 1970; 21: 359-384

86 Kiba T, Takei K, Kojima M, Sakakibara H. Side-chain modification of cytokinins controls shoot growth in Arabidopsis. Dev Cell 2013; 27: 452-461

87 Corbesier L, Prinsen E, Jacqmard A, Lejeune P, Onckelen HV, Périlleux C, Bernier G. Cytokinin levels in leaves, leaf exudate and shoot apical meristem of Arabidopsis thaliana during floral transition. J Exp Bot 2003; 54: 2511-2517

88 Hirose N, Takei K, Kuroha T, Kamada-Nobusada T, Hayashi H, Sakakibara $H$. Regulation of cytokinin biosynthesis, compartmentalization and translocation. J Exp Bot 2008; 59: 75-83

89 Gillissen B, Bürkle L, André B, Kühn C, Rentsch D, Brandl B, Frommer WB. A new family of high-affinity transporters for adenine, cytosine, and purine derivatives in Arabidopsis. Plant Cell 2000; 12: 291-300

90 Ko D, Kang J, Kiba T, Park J, Kojima M, Do J, Kim KY, Kwon M, Endler A, Song WY, Martinoia E, Sakakibara H, Lee Y. Arabidopsis ABCG14 is essential for the root-to-shoot translocation of cytokinin. PNAS 2014; 111: 7150-7155

91 Umehara M, Hanada A, Yoshida S, Akiyama K, Arite T, Takeda-Kamiya N, Magome H, Kamiya Y, Shirasu K, Yoneyama K, Kyozuka J, Yamaguchi S. Inhibition of shoot branching by new terpenoid plant hormones. Nature 2008; 455: 195-200

92 Gomez-Roldan V, Fermas S, Brewer PB, Puech-Pagès V, Dun EA, Pillot JP, Letisse F, Matusova R, Danoun S, Portais JC, Bouwmeester H, Bécard G, Beveridge CA, Rameau C, Rochange SF. Strigolactone inhibition of shoot branching. Nature 2008; 455: 189-194

93 Boyer FD, de Saint Germain A, Pillot JP, Pouvreau JB, Chen VX, Ramos S, Stévenin A, Simier P, Delavault P, Beau JM, Rameau C. Structure-activity relationship studies of strigolactone-related molecules for branching inhibition in garden pea: molecule design for shoot branching. Plant Physiol 2012; 159: 1524-1544

94 Zwanenburg B, Pospišil T. Structure and activity of strigolactones: new plant hormones with a rich future. Mol Plant 2013; 6: 38-62

95 Prandi C, Occhiato EG, Tabasso S, Bonfante P, Novero M, Scarpi D, Bova $M E$, Miletto I. New potent fluorescent analogues of strigolactones: synthesis and biological activity in parasitic weed germination and fungal branching. Eur J Org Chem 2011; 2011: 3781-3793

96 Akiyama K, Matsuzaki K, Hayashi H. Plant sesquiterpenes induce hyphal branching in arbuscular mycorrhizal fungi. Nature 2005; 435: 824-827

97 López-Ráez JA, Charnikhova T, Gómez-Roldán V, Matusova R, Kohlen W, De Vos R, Verstappen F, Puech-Pages V, Bécard G, Mulder P, Bouwmeester $H$. Tomato strigolactones are derived from carotenoids and their biosynthesis is promoted by phosphate starvation. New Phytol 2008; 178: $863-874$
98 Moons A. Transcriptional profiling of the PDR gene family in rice roots in response to plant growth regulators, redox perturbations and weak organic acid stresses. Planta 2008; 229: 53-71

99 Kretzschmar T, Kohlen W, Sasse J, Borghi L, Schlegel M, Bachelier JB, Reinhardt D, Bours R, Bouwmeester HJ, Martinoia E. A petunia ABC protein controls strigolactone-dependent symbiotic signalling and branching. Nature 2012; 483: 341-344

100 Kohlen W, Charnikhova T, Liu Q Bours R, Domagalska MA, Beguerie S, Verstappen F, Leyser O, Bouwmeester H, Ruyter-Spira C. Strigolactones are transported through the xylem and play a key role in shoot architectural response to phosphate deficiency in nonarbuscular mycorrhizal host Arabidopsis. Plant Physiol 2011; 155: 974-987

101 Yang H, Murphy AS. Functional expression and characterization of Arabidopsis ABCB, AUX 1 and PIN auxin transporters in Schizosaccharomyces pombe. Plant J 2009; 59: 179-191

102 Berman HM, Westbrook J, Feng Z, Gilliland G, Bhat TN, Weissig H, Shindyalov IN, Bourne PE. The Protein Data Bank. Nucl Acids Res 2000; 28 : 235-242

103 Rutledge RM, Esser L, Ma J, Xia D. Toward understanding the mechanism of action of the yeast multidrug resistance transporter Pdr5 p: a molecular modeling study. J Struct Biol 2011; 173: 333-344

104 The UniProt Consortium. Activities at the Universal Protein Resource (UniProt), nucleic acids res. 42: D191-D198 (2014). Available at http://uniprot.org. Accessed July 1, 2014

105 Claros MG, von Heijne G. TopPred II: an improved software for membrane protein structure predictions. Comput Appl Biosci 1994; 10: 685-686

106 Cserzö M, Wallin E, Simon I, von Heijne G, Elofsson A. Prediction of transmembrane alpha-helices in prokaryotic membrane proteins: the dense alignment surface method. Protein Eng 1997; 10: 673-676

107 Hofman K, Stoffel W. TMbase - a database of membrane spanning proteins segments. Biol Chem Hoppe Seyler 1993; 347: 166

108 Hirokawa T, Boon-Chieng S, Mitaku S. SOSUI: classification and secondary structure prediction system for membrane proteins. Bioinformatics 1998; 14: 378-379

109 Pasquier C, Promponas VJ, Palaios GA, Hamodrakas JS, Hamodrakas SJ. A novel method for predicting transmembrane segments in proteins based on a statistical analysis of the SwissProt database: the PRED-TMR algorithm. Protein Eng 1999; 12: 381-385

110 Juretić $D$, Zoranić $L$, Zucić $D$. Basic charge clusters and predictions of membrane protein topology. J Chem Inf Comput Sci 2002; 42: 620632

111 Krogh A, Larsson B, von Heijne G, Sonnhammer EL. Predicting transmembrane protein topology with a hidden Markov model: application to complete genomes. J Mol Biol 2001; 305: 567-580

112 Jones DT, Taylor WR, Thornton JM. A model recognition approach to the prediction of all-helical membrane protein structure and topology. Biochemistry 1994; 33: 3038-3049

113 Nugent T, Jones DT. Transmembrane protein topology prediction using support vector machines. BMC Bioinformatics 2009; 10: 159

114 Rost B, Yachdav G, Liu J. The PredictProtein server. Nucleic Acids Res 2004; 32: W321-W326

115 Molecular Operating Environment (MOE), 2013.08. Montreal, Canada: Chemical Computing Group, Inc.; 2013

116 Eswar N, Webb B, Marti-Renom MA, Madhusudhan MS, Eramian D, Shen MY, Pieper $U$, Sali A. Comparative protein structure modeling using Modeller. Curr Protoc Bioinformatics 2006; Chapter 5: Unit 5.6

117 Laskowski RA, MacArthur MW, Moss DS, Thornton JM. PROCHECK: a program to check the stereochemical quality of protein structures. J Appl Crystallogr 1993; 26: 283-291

118 Laskowski RA, Hutchinson EG, Michie AD, Wallace AC, Jones ML, Thornton JM. PDBsum: a Web-based database of summaries and analyses of all PDB structures. Trends Biochem Sci 1997; 22: 488-490

119 Pettersen EF, Goddard TD, Huang CC, Couch GS, Greenblatt DM, Meng $E C$, Ferrin TE. UCSF Chimera-a visualization system for exploratory research and analysis. J Comput Chem 2004; 25: 1605-1612

120 The PyMOL Molecular Graphics System, Version 1.6. Schrödinger, LLC. Available at http://www.pymol.org. Accessed January 1, 2014 